\title{
Heterozygosity for the Mood Disorder-Associated Variant Gln460Arg Alters P2X7 Receptor Function and Sleep Quality
}

\author{
Michael W. Metzger, ${ }^{1 \star}$ Sandra M. Walser, ${ }^{1 \star}$ Nina Dedic, ${ }^{1 \star}$ Fernando Aprile-Garcia, ${ }^{2}$ Vladimira Jakubcakova, ${ }^{1}$ \\ Marek Adamczyk, ${ }^{1}$ Katharine J. Webb, ${ }^{1}$ Manfred Uhr, ${ }^{1}$ Damian Refojo, ${ }^{1,2}$ @Mathias V. Schmidt, ${ }^{1}$ OElisabeth Friess, ${ }^{1}$ \\ Axel Steiger, ${ }^{1}$ Mayumi Kimura, ${ }^{1}$ Alon Chen, ${ }^{1,3}$ Florian Holsboer, ${ }^{1}{ }^{-}$Eduardo Arzt, ${ }^{1,2}$ Wolfgang Wurst, ${ }^{4,5,6,7}$ \\ and $\mathbb{D}^{-J a n}$ M. Deussing ${ }^{1}$ \\ ${ }^{1}$ Max Planck Institute of Psychiatry, 80804 Munich, Germany, ${ }^{2}$ Instituto de Investigación en Biomedicina de Buenos Aires (IBioBA), National Scientific and \\ Technical Research Council (CONICET)-Partner Institute of the Max Planck Society, Godoy Cruz 2390, C1425FQD, Buenos Aires, Argentina, ${ }^{3}$ Department of \\ Neurobiology, Weizmann Institute of Science, Rehovot 76100, Israel, ${ }^{4}$ Helmholtz Zentrum München, German Research Center for Environmental Health, \\ Institute of Developmental Genetics, 85764 Neuherberg, Germany, ${ }^{5}$ Technische Universität München-Weihenstephan, Chair of Developmental Genetics c/o \\ Helmholtz Zentrum München, 85764 Neuherberg, Germany, ${ }^{6} \mathrm{German}$ Center for Neurodegenerative Diseases (DZNE), Site Munich, 81377 Munich, Germany, and \\ ${ }^{7}$ Munich Cluster for Systems Neurology (SyNergy), Adolf-Butenandt-Institut, Ludwig-Maximilians-Universität München, 80336 Munich, Germany
}

A single nucleotide polymorphism substitution from glutamine ( $\mathrm{Gln}, \mathrm{Q}$ ) to arginine (Arg, R) at codon 460 of the purinergic P2X7 receptor (P2X7R) has repeatedly been associated with mood disorders. The P2X7R-Gln460Arg variant per se is not compromised in its function. However, heterologous expression of P2X7R-Gln460Arg together with wild-type P2X7R has recently been demonstrated to impair receptor function. Here we show that this also applies to humanized mice coexpressing both human P2X7R variants. Primary hippocampal cells derived from heterozygous mice showed an attenuated calcium uptake upon agonist stimulation. While humanized mice were unaffected in their behavioral repertoire under basal housing conditions, mice that harbor both P2X7R variants showed alterations in their sleep quality resembling signs of a prodromal disease stage. Also healthy heterozygous human subjects showed mild changes in sleep parameters. These results indicate that heterozygosity for the wild-type P2X7R and its mood disorder-associated variant P2X7RGln460Arg represents a genetic risk factor, which is potentially able to convey susceptibility to mood disorders.

Key words: humanized mouse model; mood disorder; P2X7 receptor; purinergic signaling; sleep; stress

\section{Significance Statement}

Depression and bipolar disorder are the most common mood disorders. The P2X7 receptor (P2X7R) regulates many cellular functions. Its polymorphic variant $\mathrm{Gln} 460 \mathrm{Arg}$ has repeatedly been associated with mood disorders. Genetically engineered mice, with human P2X7R, revealed that heterozygous mice (i.e., they coexpress the disease-associated Gln460Arg variant together with its normal version) have impaired receptor function and showed sleep disturbances. Human participants with the heterozygote genotype also had subtle alterations in their sleep profile. Our findings suggest that altered P2X7R function in heterozygote individuals disturbs sleep and might increase the risk for developing mood disorders.

\section{Introduction}

Major depression (MD) and bipolar disorder (BD) represent the most prevalent mood disorders (Collins et al., 2011). Despite

Received Nov. 9, 2016; revised May 31, 2017; accepted June 12, 2017.

Author contributions: M.K., F.H., E.A., W.W., and J.M.D. designed research; M.W.M., S.M.W., N.D., F.A.-G., V.J., M.A., K.J.W., M.U., M.V.S., E.F., M.K., and J.M.D. performed research; M.W.M., S.M.W., N.D., F.A.-G., V.J., M.A., K.J.W., M.U., D.R., M.V.S., E.F., A.S., M.K., A.C., F.H., E.A., W.W., and J.M.D. analyzed data; M.W.M., N.D., and J.M.D. wrote the paper.

This work was partially supported by the German Federal Ministry of Education and Research, within the framework of the e:Med research and funding concept (IntegraMent: Grant FKZ 01ZX1314H), the Marie Skłodowska-Curie innovative training network Purines $\mathrm{DX}$, and by the program supporting scientific and technological cooperation between Germany and Argentina (Grant FKZ 01DN16028). We thank Adrianne Tasdemir, Susanne Weidemann, Sabrina Bauer, Cornelia Flachskamm, Marcel Schieven, and Stefanie Unkmeir for excellent technical support; and their high heritability, the identification of susceptibility genes has been challenging, with many discoveries failing replication.

\footnotetext{
Judit Oldekamp for assisting targeting vector generation. We also thank Jessica Keverne for professional English editing, formatting, and scientific input.

${ }^{*}$ M.W.M., S.M.W., and N.D. contributed equally to this work.

The authors declare no competing financial interests.

Correspondence should be addressed to Jan M. Deussing, Molecular Neurogenetics, Department of Stress Neurobiology and Neurogenetics, Max Planck Institute of Psychiatry, Kraepelinstrasse 2-10, D-80804 Munich, Germany, E-mail: deussing@psych.mpg.de.

F. Aprile-Garcia's present address: Max Planck Institute of Immunobiology and Epigenetics, 79108 Freiburg, Germany.

F. Holsboer's present address: HMNC Brain Health, 80539 Munich, Germany.

DOI:10.1523/JNEUROSCI.3487-16.2017

Copyright $\odot 2017$ the authors $\quad 0270-6474 / 17 / 3711688-13 \$ 15.00 / 0$ 
This is largely owing to the inherent phenotypic and genetic heterogeneity of these disorders as well as the difficulty in controlling for environmental factors, which interfere with disease etiology (Bosker et al., 2011).

A potential susceptibility gene for mood disorders is $P 2 R X 7$, which is located on chromosome $12 \mathrm{q} 24$, a region that has been repeatedly associated with $\mathrm{MD}$ and BD (Degn et al., 2001; Abkevich et al., 2003). The $P 2 R X 7$ gene encodes the purinergic P2X7 receptor $(\mathrm{P} 2 \mathrm{X} 7 \mathrm{R})$, which is a member of the P2X family of ATPgated ion channels (Surprenant et al., 1996; Khakh and North, 2006). Unlike other family members, $P 2 X 7$ subunits primarily form homotrimeric complexes (Torres et al., 1999; Nicke, 2008). The nonsynonymous single nucleotide polymorphism (SNP) rs2230912 (base change $1405 \mathrm{~A}>\mathrm{G}$ ), which leads to a substitution of glutamine (Gln, Q) by arginine (Arg, R) at codon 460 (Gln460Arg, Q460R), has been associated with mood disorders (Barden et al., 2006; Lucae et al., 2006; Nagy et al., 2008; Hejjas et al., 2009; McQuillin et al., 2009; Soronen et al., 2011).

The P2X7R is well known for its presence in immune, endothelial, and epithelial cells where it regulates various aspects of immune function, including expression and secretion of cytokines and other inflammatory mediators (Wiley et al., 2011). Owing to its association with mood disorders and its involvement in neuroinflammatory processes, the role of the P2X7R in the CNS has been attracting increasing attention (Bartlett et al., 2014; Sperlágh and Illes, 2014). In the CNS, P2X7R expression has been detected in all of the main cell lineages including astrocytes, oligodendrocytes, microglia, and neurons. Under baseline conditions, its neuronal expression is restricted to excitatory neurons of the hippocampus (Metzger et al., 2017). Pharmacological approaches and knock-out $(\mathrm{KO})$ mice have demonstrated that P2X7R contributes to the regulation of various neuronal functions including neurotransmitter release and synaptic transmission (Deuchars et al., 2001; Miras-Portugal et al., 2003; Papp et al., 2004). In addition, KO mice revealed P2X7R-dependent alterations in different aspects of emotional behavior related to mood disorders (Basso et al., 2009; Boucher et al., 2011; Csölle et al., 2013).

However, several studies have not detected statistically significant associations of the Gln460Arg polymorphism with mood disorders (Green et al., 2009; Grigoroiu-Serbanescu et al., 2009; Yosifova et al., 2009; Lavebratt et al., 2010; Backlund et al., 2011; Viikki et al., 2011; Halmai et al., 2013). Therefore, we set out to functionally validate the association of the Gln460Arg polymorphism in both genetically engineered mouse models humanized for the P2X7R and human subjects specifically genotyped for rs2230912. In contrast to the many loss-of-function and gain-offunction polymorphisms that have been identified, the mood disorder-associated P2X7R-Gln460Arg variant is not compromised in its activity (Roger et al., 2010; Aprile-Garcia et al., 2016). Similar to previous in vitro studies, we demonstrate here that only the coexpression of hP2X7R-Gln460Arg with hP2X7R-wild-type (WT) impairs normal receptor function in mice. Accordingly, humanized mice expressing either human WT P2X7R or hP2X7RGln460Arg presented no pathological findings. However, mice heterozygous for both variants exhibited significant differences in sleep parameters, which remarkably paralleled the sleep alterations seen in healthy heterozygous human subjects. Finally, the interaction of this genetic predisposition together with chronic stress as an environmental challenge revealed an increased vulnerability of heterozygous humanized P2X7R mice to develop mood disorder-like phenotypes.

\section{Materials and Methods}

Generation of humanized P2X7R mice. Humanized P2X7R mice ( $h P 2 R X 7)$ were generated by knockin of the Gln460Arg variant of the human P2X7R cDNA to the murine P2rx7 locus using standard genetargeting procedures in mouse embryonic stem cells, as previously described (Metzger et al., 2017). Briefly, murine exon 2 was replaced by the human P2RX7 cDNA comprising exons 2-13. The variant of the human cDNA was constructed as previously described (Aprile-Garcia et al., 2016) and appeared with the following amino acid sequences at the 11 positions of previously identified haplotypes P2X7-1, P2X7-2, and P2X7-4 (Stokes et al., 2010): Val-76, Gly-150, His-155, Arg-270, Arg-276, Arg-307, Ala348, Thr-357, Arg-460, Glu-496, and Ile-568. Mice were kept on a mixed 129S2/SvPas $\times$ C57BL/6J background. General genotyping of humanized mice was performed as previously described (Metzger et al., 2017). Humanized alleles were identified by PCR using primers 5 '-GTG-GATGAA-TCC-CAC-ATT-AGG-ATG-GTG-3' and 5'-TAC-TGC-CCT-TCACTC-TTC-GGA-AAC- $3^{\prime}$, resulting in a 557 bp product followed by a restriction digest of the PCR product with PvuII resulting in 171, 332, and $54 \mathrm{bp}$ fragments for the humanized WT (Gln460) allele, and 503 and $54 \mathrm{bp}$ fragments for the humanized mutant allele (Arg460).

Reverse transcriptase quantitative real-time PCR. For the quantification of mRNA expression levels, RNA was isolated using TRIzol reagent (catalog \#15596-026, Thermo Fisher Scientific) and transcribed to cDNA using the SuperScript II Reverse Transcriptase Kit (catalog \#18064014, Thermo Fisher Scientific) following the manufacturer protocols. Quantitative PCR was performed in a LightCycler96 (Roche Applied Science) using the Master SYBR Green Kit I (catalog \#03003230001, Roche Diagnostics). The following primers were used: hP2RX7-for $5^{\prime}$-ATGTCA-AGG-GCC-AAG-AAG-TC-3'; and hP2RX7-rev 5'-AGG-AATCGG-GGG-TGT-GTC-3'.

In situ hybridization. For in situ hybridization, ${ }^{35} \mathrm{~S}$-UTP-labeled riboprobes were hybridized on $20-\mu \mathrm{m}$-thick brain cryosections. The mousespecific P2X7R probe comprises nucleotides 1215-1636 (GenBank accession no. NM_011027). The human-specific P2X7R probe comprises nucleotides 1195-1616 (GenBank accession no. NM_002562).

Interleukin-1 $\beta$ assay. Peritoneal macrophages were isolated as previously described (Basso et al., 2009). Lipopolysaccharide (LPS) at a concentration of $3 \mu \mathrm{g} / \mathrm{ml}$ was added, and the cells were allowed to prime for $2 \mathrm{~h}$. The cells were then challenged with $1 \mathrm{~mm}$ P2X7R agonist $2^{\prime}, 3^{\prime}-\mathrm{O}-$ (benzoyl-4-benzoyl)-ATP (BzATP) for $30 \mathrm{~min}$. Supernatants were collected and analyzed for interleukin-1 $\beta$ (IL-1 $\beta$ ) using an ELISA kit following the manufacturer instructions (catalog \#KMC0011C, Thermo Fisher Scientific).

Primary hippocampal cell culture. Primary hippocampal cultures were prepared from mice at postnatal day 2. Mice were killed by decapitation, brains were dissected free of meninges, and hippocampi were isolated. Subsequently, tissues were dissociated and suspended in DMEM/F12 medium (Invitrogen) supplemented with 10\% FCS and 1\% penicillin/ streptomycin. Primary cells were cultivated in six-well plates $(200,000$ cells/well) until they reached confluency before used for calcium imaging.

Calcium imaging. Confluent cells were trypsinized and plated at a low density of 10,000 cells $/ \mathrm{cm}^{2}$ on eight-well culture slides (Nunc Lab-Tek II Chamber Slide System, Thermo Fisher Scientific) to evaluate single cells in the measurements. After $2 \mathrm{~d}$ of recovery post-trypsinization, cells were loaded for $45 \mathrm{~min}$ in darkness with Fluo-4 AM $6 \mu \mathrm{M}$ (Invitrogen) and Pluronic F- 127 0.14\% (Invitrogen) in a $\mathrm{Ca}^{2+}$ buffer ( $125 \mathrm{~mm} \mathrm{NaCl}, 5 \mathrm{~mm}$ $\mathrm{KCl}, 0.4 \mathrm{~mm} \mathrm{CaCl} 2,1 \mathrm{~mm} \mathrm{MgSO}_{4}, 5 \mathrm{~mm} \mathrm{NaHCO} 3,1 \mathrm{~mm} \mathrm{Na}_{2} \mathrm{HPO}_{4}$, $10 \mathrm{~mm}$ glucose, and $20 \mathrm{~mm}$ HEPES, $\mathrm{pH}$ 7.4), and then were placed on the stage of an Olympus IX81 inverted confocal fluorescence microscope. Microscope pictures were captured with the $10 \times$ UPlanSApo (0.4 numerical aperture) objective. Calcium imaging data are presented as $\Delta F /$ $F_{0}$, where $F_{0}$ is the resting fluorescence (before stimulation) and $\Delta F$ is the peak change in fluorescence from resting levels.

Behavioral characterization of mice. Behavioral characterization was performed using male humanized P2X7R mice (11-13 weeks of age). All mice were single housed for 2 weeks before the experiment under standard laboratory conditions and were maintained on a $12 \mathrm{~h} \mathrm{light/dark}$ 
cycle (lights on from 7:00 A.M. until 7:00 P.M.), with food and water provided ad libitum. All animal experiments were conducted in accordance with the Guide for the Care and Use of Laboratory Animals of the Government of Bavaria, Germany. Behavioral phenotyping comprised the open field (OF) test, elevated plus maze (EPM), dark-light box (DaLi) test, forced swim test (FST), social approach/avoidance test, and female urine sniffing test (FUST), which were conducted as previously described (Malkesman et al., 2010; Hartmann et al., 2012a; Yen et al., 2012). In the EPM. The open arm time is calculated in relation to closed arm time and is consequently depicted in percentages. The open arm time was calculated as follows: open arm time/(open arm time + closed arm time) $\times$ 100. Mice were excluded from analysis in the EPM if they fell off the platforms. If mice did not move throughout the entire course of the OF test, they were excluded from the analysis. Mice that failed to approach the cotton tip during the water and urine trial were excluded from the FUST analysis.

Chronic social defeat stress paradigm. Male mice (11-13 weeks of age) were submitted to undergo chronic social defeat stress (CSDS) for 21 consecutive days as previously described (Hartmann et al., 2012a).

Sleep phenotyping in mice. To monitor spontaneous sleep-wake behavior, mice were chronically implanted with electroencephalographic (EEG) and electromyographic (EMG) electrodes. The polysomnographic recording setup was the same as previously reported (Kimura et al., 2010). EEG and EMG recordings (EGErA Data Acquisition System, SEA) were performed continuously for $24 \mathrm{~h}$ in unrestrained adult male hP2X7R mice. Vigilance states are defined as wake, non-rapid eye movement (REM) sleep (NREMS), or REM sleep (REMS), respectively, in $4 \mathrm{~s}$ epochs and manually corrected if necessary.

Sleep phenotyping in humans. The study followed the guidelines in the Declaration of Helsinki. The ethical review board approved the study, and prior written informed consent was obtained from the participants. We investigated the sleep EEG recordings of $n=53$ young healthy male subjects (age range, $18-30$ years) in relation to their Gln460Arg variant (rs2230912) of the P2RX7 gene. Thirty-nine subjects (mean \pm SEM age, $25.74 \pm 0.44$ years) were identified as carriers of the homozygous (A/A) gene variant, whereas $n=14$ subjects (mean \pm SEM age, $25.5 \pm 0.65$ years) were heterozygous individuals (A/G genotype). No homozygous G/G carriers were identified (minor allele frequency, 0.05).

Polysomnographic recordings (Comlab 32 Digital Sleep Lab, Schwarzer) were performed according to the international 10-20 electrode system. EEG electrodes included F3, F4, C3, C4, P3, P4, O1, and $\mathrm{O}_{2}$, which were referenced against the contralateral mastoid. Sleep stages were visually scored according to the standard guidelines (Rechtschaffen and Kales, 1968). Details of the study design used in the human polysomnographic set up are described in the study by Adamczyk et al. (2015).

Statistical analyses. Data and statistical analysis were performed with the computer programs GraphPad Prism version 5.0 (GraphPad; RRID: SCR_002798) and SPSS version 16 (SPSS; RRID:SCR_002865). All results are shown as the mean \pm SEM. Sample sizes were chosen based on previous publications reporting similar group sizes. Investigators were blinded to the experimental groups during the experiments and data analysis.

For calcium imaging, data ANOVA with repeated-measures (RM) design were applied. Real-time PCR data were analyzed by one-way ANOVA with a Scheffe's post hoc test.

The effects of genotype on mouse sleep and of genotype and stress on behavior and neuroendocrine data were examined by two-way multivariate ANOVA (MANOVA). ANOVA with repeated-measures design was applied for the assessment of fur state progression and locomotion in the OF test. A Tukey's (behavioral characterization) or a Bonferroni's (sleep phenotyping) post hoc test was applied whenever significant main or interaction effects were observed. Significance was accepted at $p=0.05$. Subjects were assigned to treatment groups based on their genotype without using a specific method. An $F$ test (for $t$ tests) or Bartlett's test (for ANOVA) was performed to estimate the variation within each group of data. The statistically compared groups had similar variance.

Human sleep data were analyzed as follows: The assumptions of parametric tests were checked for each investigated parameter. Normal distribution was controlled via the Kolmogorov-Smirnov test, and vari- ances were compared with the $F$ test. Prerequisites were considered to be violated if the appropriate test showed a significant result at the $5 \%$ level. If data did not fulfill these criteria, they were either power transformed (when skewed to the left; sleep period time) or log transformed (when skewed to the right; all EEG spectral data), respectively, before statistical analysis. MANOVA was performed to compare sleep architecture and sleep continuity between genotypes (A/A, A/G). Two-way mixed-model ANOVA with the between-subject factor genotype (A/A, A/G), and the within-subject factor derivation (F3A2, C3A3, P3A2, and O1A2) was performed for EEG power activity. All univariate post hoc comparisons of means between the genotypes were performed with the two-tailed unpaired $t$ test.

\section{Results}

\section{P2X7R function is attenuated in heterozygous humanized} mice coexpressing hP2X7R-WT and hP2X7R-Gln460Arg

To investigate the impact of the mood disorder-associated Gln460Arg polymorphism in vivo we humanized the murine $\mathrm{P} 2 \mathrm{X} 7$ receptor ( $\mathrm{mP} 2 \mathrm{X} 7 \mathrm{R}$ ) by substituting the murine exon 2 with a human cDNA expression unit, which covers exons 2-13 and in addition carries the polymorphism (hP2X7R-Gln460Arg; Fig. $1 A, B)$. This strategy was chosen to maintain all regulatory elements crucial for proper temporal and spatial expression of the humanized P2X7R. To address the significant species-specific difference with respect to the affinity of the receptor toward its ligand and different modulators, we used a mouse line expressing the humanized WT P2X7R (hP2X7R-WT) instead of mP2X7R, which enabled direct comparison (Fig. 1C; Metzger et al., 2017). The temporal and spatial expression of hP2X7R variants in both humanized P2X7R mouse lines ( $h P 2 R X 7)$, either homozygous for the WT hP2X7R-Gln460 (P2rx $7^{h G \ln 460 / h G \ln 460}$, referred to as $\left.P 2 r x 7^{h W T}\right)$ or for the hP2X7R-Arg460 variant $\left(P 2 r x 7^{h A r g 460 / h A r g 460}\right.$, referred to as $\left.P 2 r x 7^{h \mathrm{Q} 460 R}\right)$ is indistinguishable from endogenous $\mathrm{mP} 2 \mathrm{X} 7 \mathrm{R}$ expression. This was demonstrated by in situ hybridization using species-specific riboprobes, which revealed the characteristic strong expression of P2X7R in the hippocampal CA3 region (Fig. $1 D$ ). We further confirmed that the expression levels of hP2X7R-WT and hP2X7R-Gln460Arg were identical, thus enabling a meaningful comparison of the humanized mouse lines (Fig. 1E). Both lines express a fully functional hP2X7R, as indicated by their capability to induce the release of IL- $1 \beta$ from peritoneal macrophages stimulated with LPS and BzATP (Fig. $1 F$ ).

Our previous in vitro results indicated that coexpression of hP2X7R-Q460R and hP2X7R-WT reduces receptor activity (AprileGarcia et al., 2016). Therefore, $P 2 r x 7^{h W T}$ and $P 2 r x 7^{h Q 460 R}$ mice were intercrossed to yield heterozygous $P 2 r x 7^{h G \ln 460 / h A r g 460}$ animals (referred to as $P 2 r x 7^{h H E T}$ ), which were finally interbred to obtain $P 2 r x 7^{h W T}, P 2 r x 7^{h H E T}$, and $P 2 r x 7^{h Q 460 R}$ offspring at Mendelian rates (Fig. $2 A, B$ ). We used mixed primary hippocampal cell cultures to assess $\mathrm{P} 2 \mathrm{X} 7 \mathrm{R}$ function in humanized mice in more detail. BzATP stimulation revealed an attenuated calcium uptake of primary cells derived from heterozygous $h P 2 r x 7^{h H E T}$ mice compared with those originating from homozygous $h P 2 r x 7^{h W T}$ or $h P 2 r x 7^{h Q 460 R}$ mice (RM ANOVA: time: $F_{(29,406)}=56.07, p<$ 0.0001 ; time $\times$ genotype: $F_{(58,406)}=1.52, p=0.012$; genotype: $F_{(2,406)}=8.96, p=0.003 ; n=6 P 2 r x 7^{h W T}, n=7 P 2 r x 7^{h H E T}, n=$ and 4 P2rx $7^{\text {hQ460R }}$; Fig. $\left.2 C\right)$.

A comprehensive basal behavioral phenotyping of humanized mice did not reveal any significant differences in emotional behavior as assessed by the OF test (one-way ANOVA, $F_{(2,31)}=0.84$, $p=0.44, n=11-12$ ), EPM (one-way ANOVA, $F_{(2,33)}=0.11, p=$ $0.89, n=11-13$ ), DaLi test (one-way ANOVA, $F_{(2,32)}=1.71, p=$ $0.19, n=11-12$ ), or FST (one-way ANOVA, $F_{(2,33)}=0.82, p=0.45$, $n=11-12$ ) under standard housing conditions (Fig. $2 D-G$ ). 
A
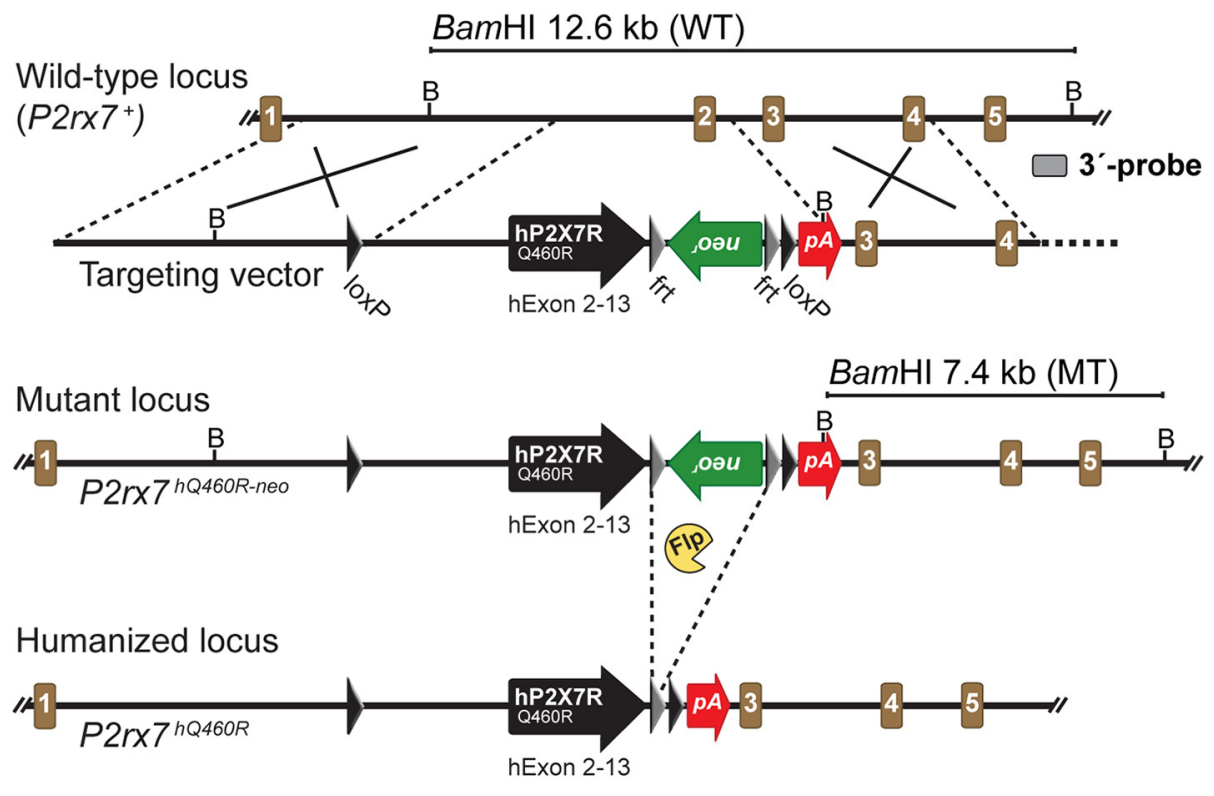

B

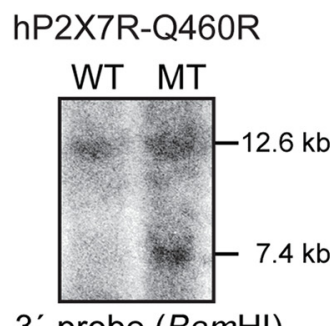

3'-probe (BamHI)

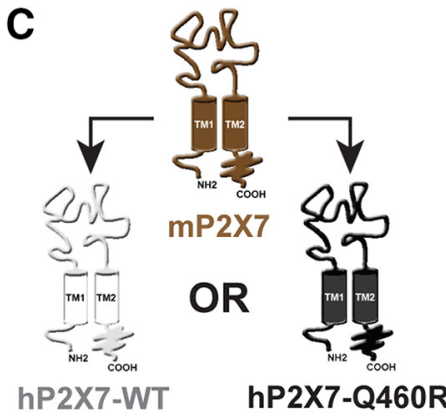

D

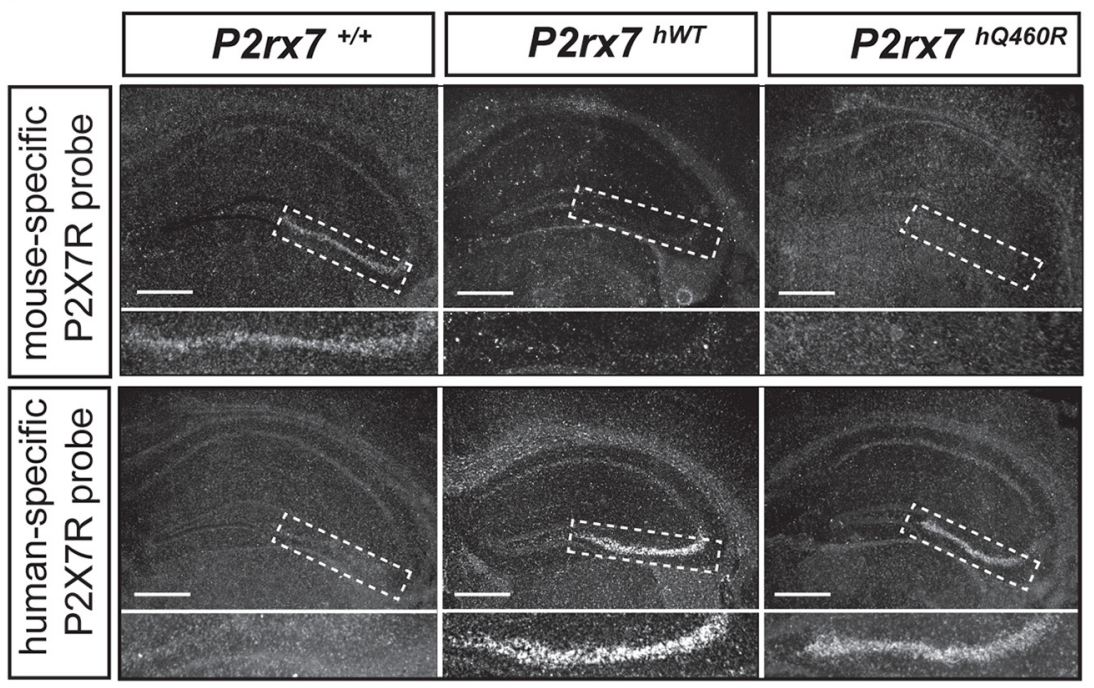

E

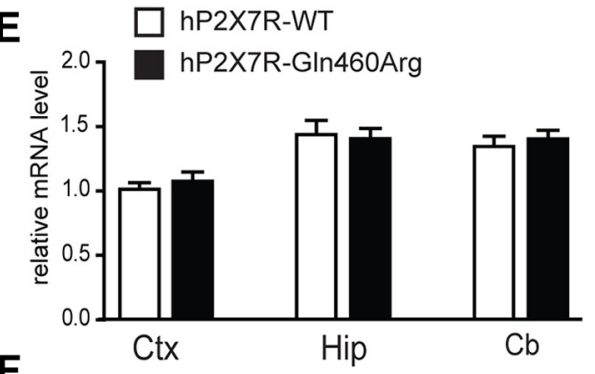

$F$

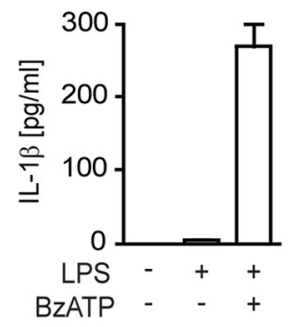

Figure 1. Establishment of humanized P2X7R mice ( $h P 2 R X 7)$. A, Targeting strategy for knockin of the human P2RX7 cDNA into the mouse P2rX7 locus. Partial restriction maps [only relevant BamHI (B) sites are depicted] of the wild-type $P 2 r x 7$ locus, targeting vector, and mutant locus following homologous recombination and loxP-flanked humanized locus after Flp recombinasemediated deletion of the neomycin selection marker ( $\mathrm{pA} ; 4 \times$ polyadenylation signal). $\boldsymbol{B}$, Southern blot analysis of genomic DNA from an embryonic stem cell clone targeted with the human P2X7R-Q460R construct, which was used to generate $P 2 r x 7^{Q 460 R}$ mice. The targeted allele is indicated by the presence of an additional $7.4 \mathrm{~kb}$ fragment. $C$, General strategy to substitute the murine P2X7R by the human WT receptor or its P2X7R-0460R variant. $D$, The mRNA expression of human P2X7R in knock-in mice fully recapitulates endogenous expression of murine P2X7R, as demonstrated by in situ hybridization on coronal brain sections. Depicted are photomicrographs of the hippocampus (scale bar, $100 \mu \mathrm{m}$ ) with magnifications of the hippocampal CA3 region shown below. $\boldsymbol{E}$, Human P2X7R mRNA is expressed at identical levels in the cortex (Ctx), hippocampus (Hip), and cerebellum (Cb) of heterozygous $P 2 r x 7^{+/ h w T}$ and $P 2 r x 7^{+/ Q 460 R}$ mice ( $\left.n=6\right)$. $\boldsymbol{E}$, Human P2X7R mRNA is expressed at identical levels in the cortex (Ctx), hippocampus (Hip), and cerebellum (Cb) of heterozygous $P 2 r x 7^{+/ h W T}$ and $P 2 r x 7^{+/ Q 460 R}$ mice $(n=6)$. $F$, Validation of hP2X7R functionality in $P 2 r x 7^{h W T}$ and $P 2 r x 7^{h Q 460 R}$ mice as determined by IL-1 $\beta$ release. Peritoneal macrophages of $P 2 r x 7^{h W T}$ and of $P 2 r x 7^{\text {hQ460R }}$ mice are able to secrete IL- $1 \beta$ in response to $L P S$ stimulation and subsequent treatment with the P2X7R agonist BzATP $(n=4)$. Data are expressed as the mean \pm SEM.

hP2X7R-WT/hP2X7R-Gln460Arg heterozygosity negatively affects sleep quality

Since impaired sleep is one of the most robust symptoms accompanying mood disorders, we additionally monitored EEG activity and assessed spontaneous sleep-wake behavior in $h P 2 R X 7$ mice. All three genotypes of $h P 2 R X 7$ mice showed unaltered nocturnal sleep-wake behavior, as indicated by the normal distribution of NREMS (two-way ANOVA: genotype: $F_{(2,360)}=0.75, p=0.75$; time: $F_{(11,360)}=68.13, p<0.0001$; genotype $\times$ time: $F_{(22,360)}=$
$1.42, p=1.10 ; n=11$ in all groups) and REMS (two-way ANOVA: genotype: $F_{(2,360)}=0.76, p=0.47$; time: $F_{(11,360)}=73.39, p<$ 0.0001 ; genotype $\times$ time: $F_{(22,360)}=2.04, p<0.05 ; n=11$ in all groups; Fig. $3 A, B$; Table 1). However, heterozygous mice showed a significantly higher number of episode entries to REMS during the light period (two-way ANOVA: genotype: $F_{(2,60)}=4.83, p<0.05$; Bonferroni's multiple comparisons test: $p<0.01$; Fig. $3 C$; Table 2), suggesting a stronger drive toward REMS and more fragmented sleep cycles compared 
A

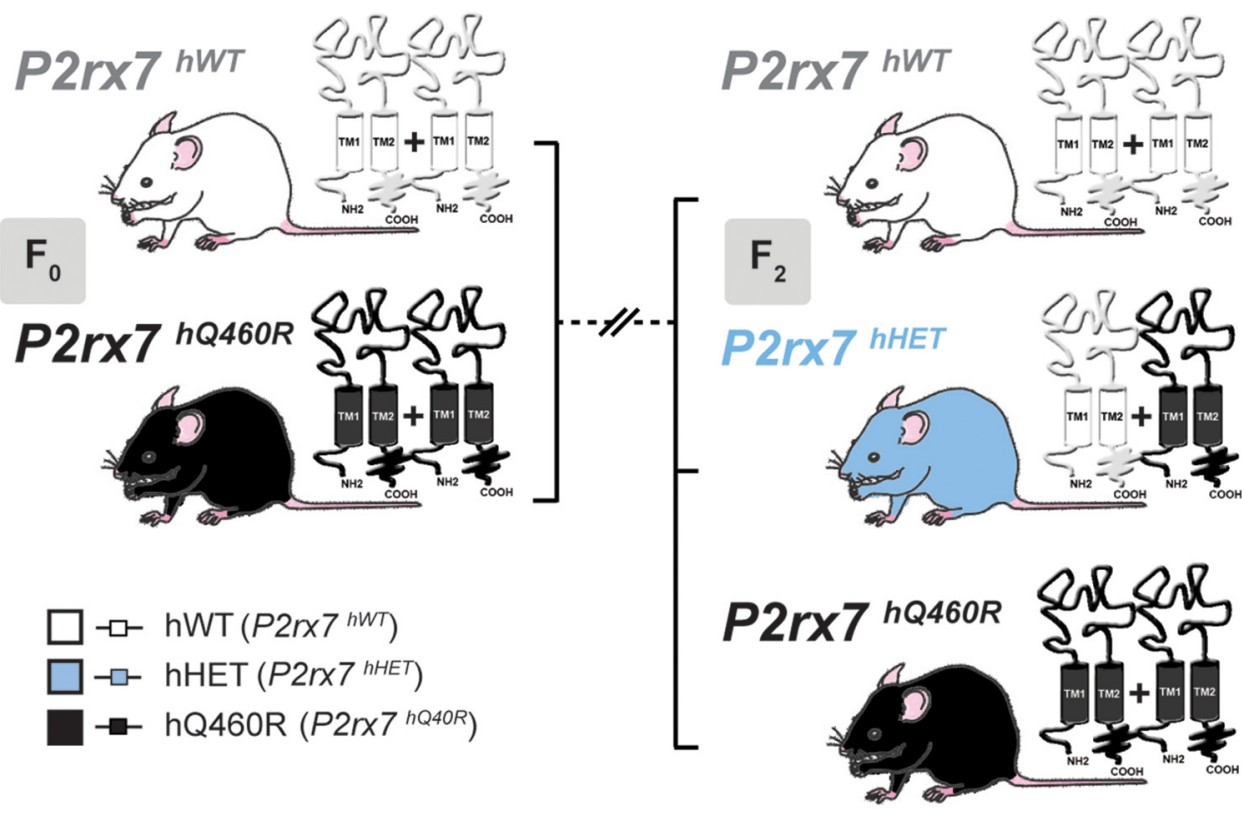

B
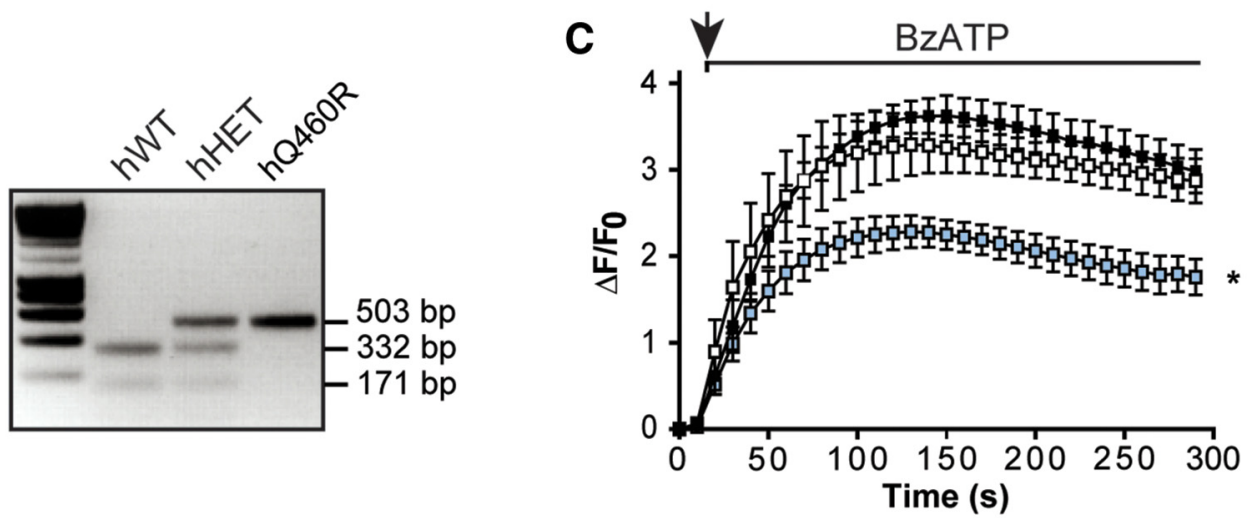

D

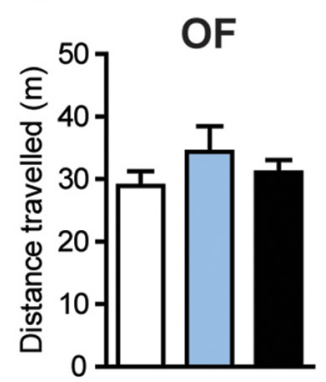

E

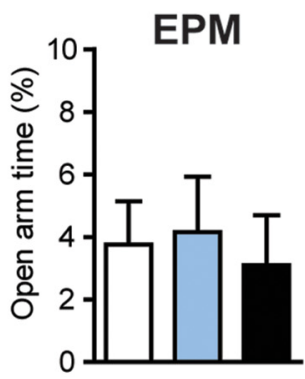

$\mathbf{F}$

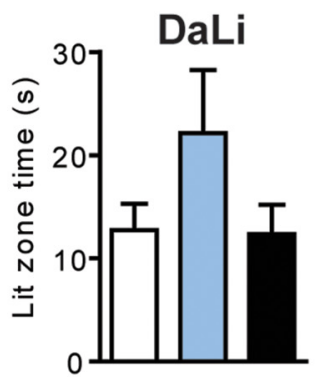

G

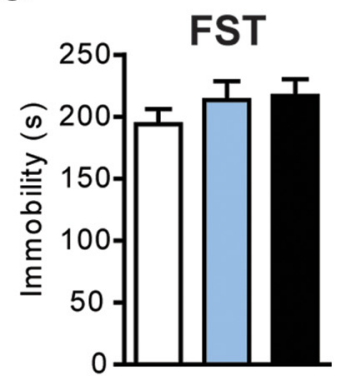

Figure 2. Generation and basal characterization of heterozygous humanized P2X7R mice. A, Scheme illustrating the generation of $P 2 r x 7^{\text {hWT }}, P 2 r x 7^{\text {hHET }}$, and $P 2 r x 7^{\text {hO4 } 460 R}$ mice. $B, G$ Genotyping was performed by PCR and subsequent restriction digestion of the $557 \mathrm{bp} \mathrm{PCR} \mathrm{product} \mathrm{with} \mathrm{Pvull.} \mathrm{C,} \mathrm{Calcium} \mathrm{uptake} \mathrm{following} \mathrm{BzATP} \mathrm{treatment} \mathrm{of} \mathrm{primary} \mathrm{hippocampal} \mathrm{cells} \mathrm{is} \mathrm{attenuated} \mathrm{in}$ heterozygous $h P 2 r x 7^{h H E T}$ mice. For each primary culture preparation, three independent measurements were performed (RM ANOVA, ${ }^{*} p<0.05, n=4-7$ ). D-G, Basal behavioral characterization of hP2X7R mice revealed no differences in the total distance traveled of the OF test $(\boldsymbol{D})$, in the time spent in the open arm of the EPM (E) or lit zone time of the DaLi test $(\boldsymbol{F})$, and in total immobility during the FST (one-way ANOVA, $n=11-12 ; \boldsymbol{G}$ ). Data are expressed as the mean \pm SEM.

with $P 2 r x 7^{h W T}$ and $P 2 r x 7^{h Q 460 R}$ mice. Additionally, slow-wave activity (SWA) during NREMS, which measures the depth of NREMS, was constantly lower in heterozygous mice (two-way ANOVA: genotype: $F_{(2,168)}=11.23, p<0.0001$; light period; $F_{(2,168)}=3.85, p<0.05$; dark period; $n=9-11$; Fig. $3 D$; Table $1)$. Accordingly, only a small amount of deep NREMS $\left(\mathrm{SWS}_{2}\right.$; containing $>50 \%$ of delta activity) was detected in $P 2 r x 7^{h H E T}$ mice (two-way ANOVA: genotype: $F_{(2,168)}=15.46, p<$
0.0001 ; light period; $F_{(2,168)}=8.14, p<0.001$; dark period; $n=9-11$; Fig. $3 E$; Table 1), suggesting a shallower NREMS stage. This finding is also reflected in the spectrograms, where $P 2 r x 7^{h H E T}$ mice exhibited reduced power densities in lowerfrequency activities of the EEG (Fig. $3 F$ ). These results indicate that $P 2 r x 7^{H E T}$ mice have an altered sleep architecture and attenuated quality of sleep compared with $P 2 r x 7^{h W T}$ and P2rx $7^{h Q 460 R}$ littermates. 
A

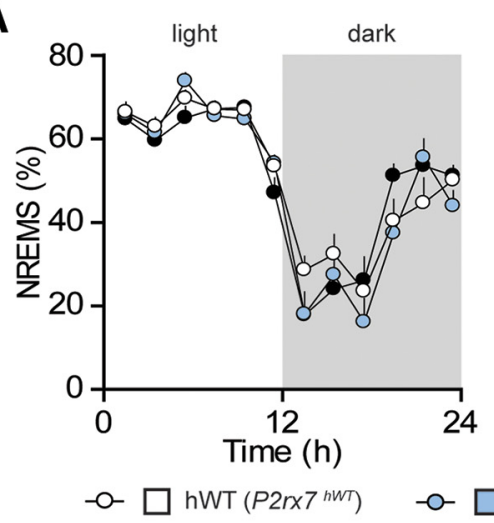

D

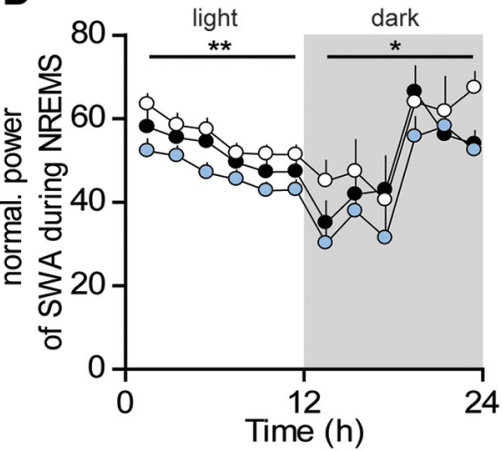

E

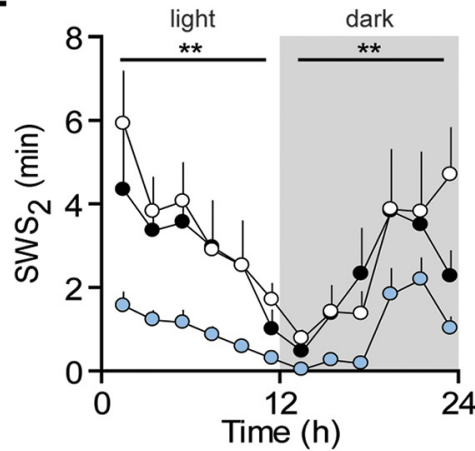

B

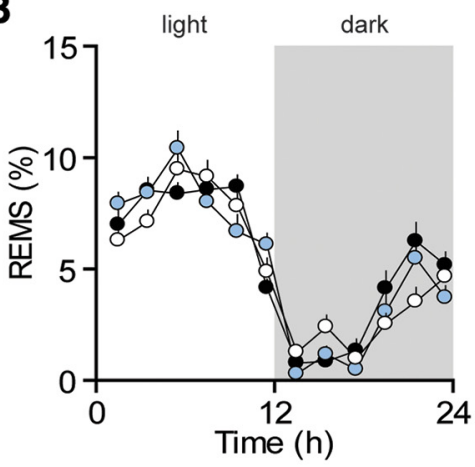

C

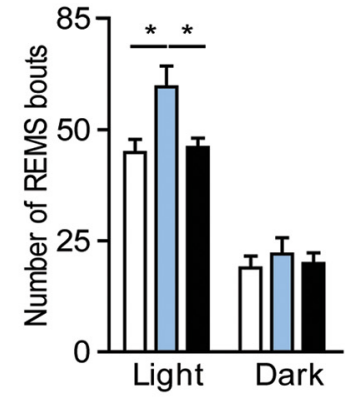

$\operatorname{hHET}\left(P 2 r \times 7^{\text {hHET }}\right) \rightarrow \square \mathrm{hQ460R}\left(P 2 r \times 7^{\text {hQ40R }}\right)$

$\mathbf{F}$
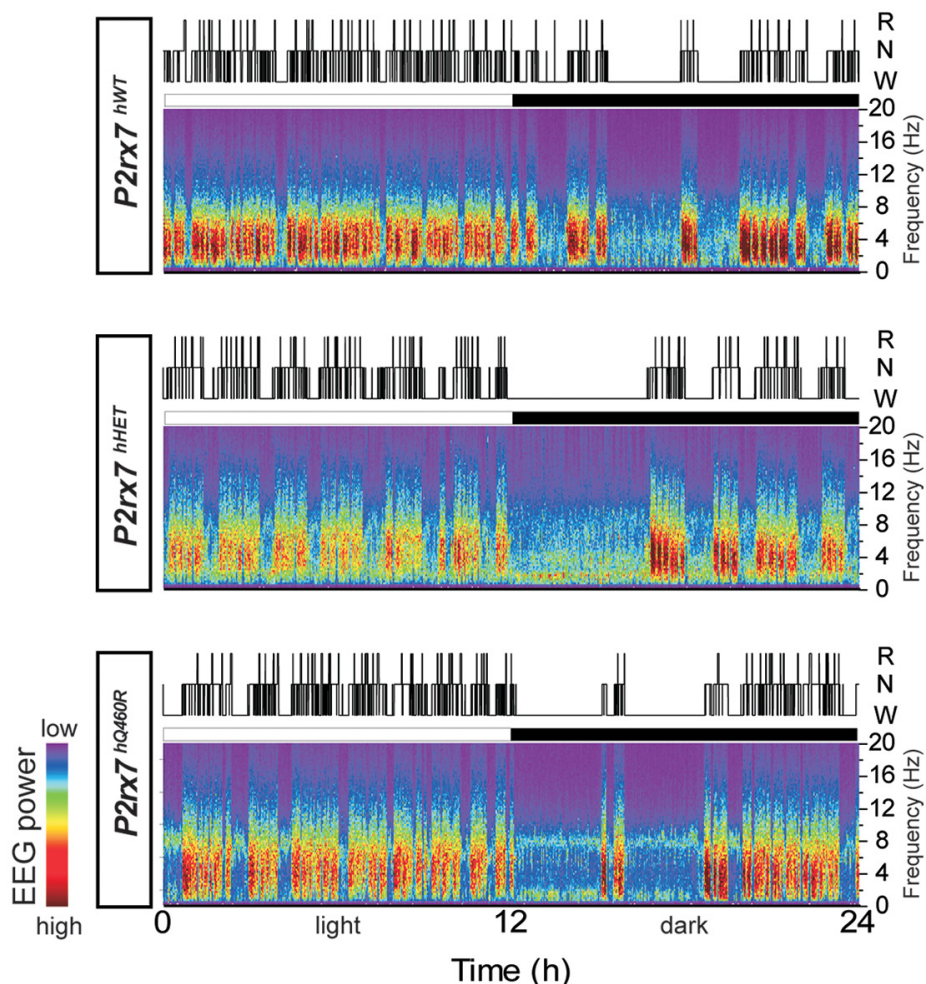

Figure 3. Heterozygosity for hP2X7R-WT with hP2X7R-GIn460Arg alters sleep parameters in $h P 2 R X 7$ mice. $\boldsymbol{A}, \boldsymbol{B}$, No genotype differences were observed in the length of NREMS $(\boldsymbol{A})$ or REMS ( $\boldsymbol{B}$ ) across the $24 \mathrm{~h}$ recording period ( $2 \mathrm{~h}$ mean $\pm \mathrm{SEM}$ ). $C$, The architecture of REMS was significantly altered in $P 2 r x 7^{\text {hHET }}$ mice that showed more frequent entries to the REMS epoch during the light period $\left(12 \mathrm{~h}\right.$ mean \pm SEM; $\left.{ }^{*} p<0.05\right)$. D , SWA during NREMS was significantly attenuated in heterozygous mice ( $2 \mathrm{~h}$ mean \pm SEM; $\left.{ }^{*} p<0.05,{ }^{* *} p<0.001\right)$. E, $P 2 r x 7^{\text {hHET }}$ mice rarely entered SWS 2 across the entire $24 \mathrm{~h}\left(2 \mathrm{~h}\right.$ mean \pm SEM; $\left.{ }^{* *} p<0.001\right)$. $\boldsymbol{F}$, Hypnograms and spectrograms of representative animals for each genotype. P2r $x 7^{\text {hHET }}$ mice show suppression of EEG power in lower-frequency bands, indicating a lower sleep quality.

Table 1. Amounts of wakefulness, NREMS and REMS, normalized SWA and SWS ${ }_{2}$ across the light/dark cycle in P2rx ${ }^{\text {hWT }}$, P2rx $7^{\text {hHET }}$, and P2rx $7^{\text {hQ460R }}$ mice

\begin{tabular}{|c|c|c|c|c|c|c|c|c|c|c|}
\hline & \multicolumn{5}{|l|}{ Light } & \multicolumn{5}{|l|}{ Dark } \\
\hline & Wake (\%) & NREMS (\%) & REMS (\%) & SWA & $\mathrm{SWS}_{2}(\mathrm{~min})$ & Wake (\%) & NREMS (\%) & REMS (\%) & SWA & $\mathrm{SWS}_{2}(\mathrm{~min})$ \\
\hline & $27.83 \pm 2.89$ & $64.24 \pm 2.36$ & $7.93 \pm 0.62$ & $60.19 \pm 1.59$ & $3.49 \pm 0.43$ & $63.96 \pm 5.04$ & $33.09 \pm 4.34$ & $2.38 \pm 0.59$ & $60.88 \pm 3.29$ & $2.66 \pm 0.48$ \\
\hline hHET & $30.61 \pm 2.93$ & $61.83 \pm 2.44$ & $7.56 \pm 0.55$ & $46.92 \pm 1.14$ & $0.95 \pm 0.13$ & $59.02 \pm 5.64$ & $37.35 \pm 4.93$ & $3.10 \pm 0.70$ & $44.30 \pm 3.74$ & $0.92 \pm 0.25$ \\
\hline hQ460R & $28.13 \pm 2.66$ & $64.41 \pm 2.21$ & $7.46 \pm 0.53$ & $51.98 \pm 1.40$ & $2.96 \pm 0.34$ & $60.38 \pm 3.69$ & $36.62 \pm 3.18$ & $2.57 \pm 0.45$ & $49.37 \pm 3.34$ & $2.29 \pm 0.39$ \\
\hline$p$ value & 0.7506 & 0.6871 & 0.8299 & $<0.0001$ & $<0.0001$ & 0.7609 & 0.7479 & 0.6780 & 0.0059 & 0.0076 \\
\hline
\end{tabular}

Data are mean values \pm SEM; $n=9, P 2 r x 7^{\text {hWT }}$ mice (hWT); $n=11, P 2 r x 7^{\text {hHET }}$ (hHET) and $P 2 r x 7^{\text {hQ460R }}$ (hQ460R) mice. Comparisons of the 12 hintervals of the light and the dark period between genotypes were performed by one-way ANOVA factor "genotype," followed by post hoc Bonferroni's test. The $p$ values in bold type indicate statistical significance.

Heterozygote human Gln460Arg carriers show more shallow sleep and lower sleep spindle frequency

Heterozygous $h P 2 r x 7^{h H E T}$ mice showed signs of an increased REMS pressure together with lower sleep depth, which might be indicative of a presymptomatic disease stage. Since sleep is readily accessible in humans, we comprehensively assessed sleep parameters in healthy subjects genotyped for the rs2230912 SNP (1405G>A). The macroscopic sleep architecture revealed marginally impaired 
Table 2. Average numbers and durations of wakefulness, NREMS, and REMS bouts under the baseline conditions in P2rx $7^{\text {hWT }}$, P2rx ${ }^{\text {hHET }}$, and P2rx $7^{\text {hQ460R }}$ mice

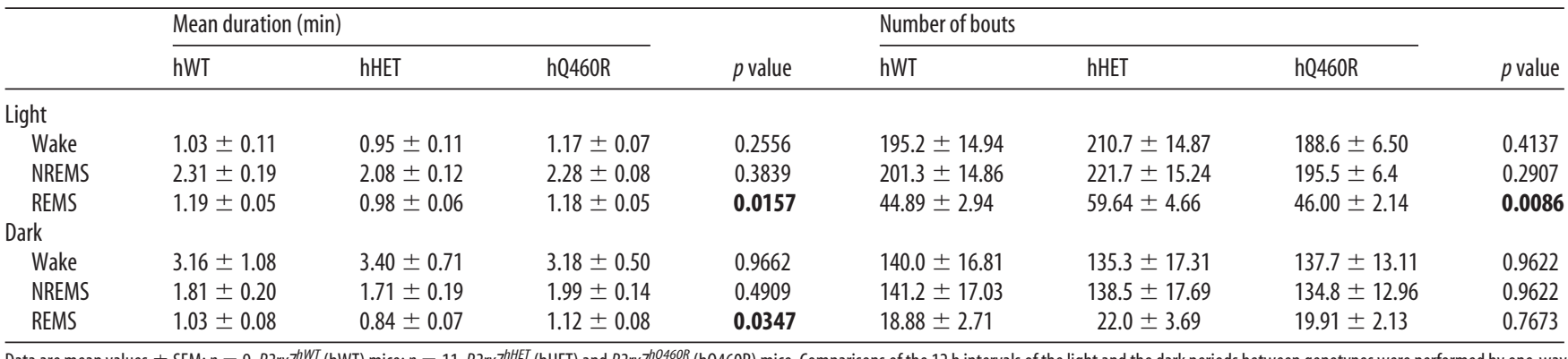

Data are mean values $\pm \mathrm{SEM} ; n=9, P 2 r x 7^{h W T}$ (hWT) mice; $n=11, P 2 r x 7^{\text {hHET }}$ (hHET) and $P 2 r x 7^{\text {hQ460R }}$ (hQ460R) mice. Comparisons of the $12 \mathrm{~h}$ intervals of the light and the dark periods between genotypes were performed by one-way ANOVA factor "genotype," followed by post hoc Bonferroni's test. The $p$ values in bold type indicate statistical significance.

Table 3. Sleep continuity, sleep architecture, and sleep-phase stability

\begin{tabular}{|c|c|c|c|}
\hline & $\begin{array}{l}\mathrm{A} / \mathrm{A} \\
(n=39)\end{array}$ & $\begin{array}{l}\mathrm{A} / \mathrm{G} \\
(n=14)\end{array}$ & $p$ value* $^{*}$ \\
\hline \multicolumn{4}{|l|}{ Sleep continuity } \\
\hline Total sleep time & $402.73 \pm 5.19$ & $382.29 \pm 11.92$ & 0.07 \\
\hline Sleep period time & $464.96 \pm 2.59$ & $449.79 \pm 8.56$ & 0.04 \\
\hline Sleep efficiency (\%) ${ }^{* *}$ & $86 \pm 1$ & $82 \pm 2$ & 0.11 \\
\hline Sleep onset latency & $15.15 \pm 2.18$ & $29.75 \pm 8.55$ & 0.05 \\
\hline All night sleep architecture & & & NS \\
\hline NREM sleep & $311.00 \pm 4.58$ & $291.89 \pm 10.20$ & \\
\hline SWS & $88.22 \pm 4.67$ & $87.29 \pm 8.84$ & \\
\hline SWS latency & $12.72 \pm 1.21$ & $11.89 \pm 1.31$ & \\
\hline Stage 1 sleep & $33.91 \pm 3.11$ & $35.14 \pm 3.73$ & \\
\hline Stage 2 sleep & $222.78 \pm 5.09$ & $204.61 \pm 8.77$ & \\
\hline Wakefulness & $25.40 \pm 3.43$ & $28.04 \pm 6.43$ & \\
\hline REM sleep & $90.50 \pm 3.87$ & $89.25 \pm 6.46$ & \\
\hline REM latency & $82.00 \pm 6.51$ & $94.50 \pm 14.91$ & \\
\hline First sleep cycle architecture & & & NS \\
\hline NREM sleep & $73.42 \pm 5.50$ & $78.32 \pm 7.68$ & \\
\hline SWS & $40.51 \pm 3.35$ & $39.61 \pm 4.90$ & \\
\hline Stage 1 sleep & $3.14 \pm 0.46$ & $7.82 \pm 2.86$ & \\
\hline Stage 2 sleep & $32.91 \pm 3.11$ & $38.71 \pm 4.68$ & \\
\hline Wakefulness & $2.21 \pm 0.60$ & $7.18 \pm 4.41$ & \\
\hline REM sleep & $11.19 \pm 1.12$ & $14.68 \pm 3.90$ & \\
\hline All night sleep-phase stability & & & NS \\
\hline Number of entries into REM sleep & $13.87 \pm 0.66$ & $13.36 \pm 1.90$ & \\
\hline Number of entries into NREM sleep & $25.62 \pm 1.37$ & $28.64 \pm 2.75$ & \\
\hline Switches from stage 2 into stage 1 /wake & $16.41 \pm 1.28$ & $21.07 \pm 2.69$ & \\
\hline Switches from SWS into stage 1/wake & $2.74 \pm 0.35$ & $2.50 \pm 0.45$ & \\
\hline \multicolumn{4}{|l|}{ First sleep cycle sleep-phase stability } \\
\hline Number of entries into REM sleep & $1.95 \pm 0.16$ & $2.50 \pm 0.42$ & 0.21 \\
\hline Number of entries into NREM sleep & $3.41 \pm 0.41$ & $6.71 \pm 1.37$ & 0.01 \\
\hline Switches from stage 2 into stage 1 /wake & $2.05 \pm 0.34$ & $5.14 \pm 1.26$ & 0.01 \\
\hline Switches from SWS into stage 1 /wake & $1.05 \pm 0.18$ & $1.29 \pm 0.27$ & 0.29 \\
\hline
\end{tabular}

Group mean \pm SEM of sleep characteristics in minutes. MANOVA revealed a marginal effect of genotype on sleep continuity, which tended to be worse in subjects with $\mathrm{A} / \mathrm{G}$ genotype $\left(F_{(4,48)}=2.388, p=0.06\right)$. MANOVA did not detect genotype differences in sleep architecture in the whole night as well as during the first sleep cycle. Also, MANOVA revealed significant lower sleep-phase stability in subjects with $\mathrm{A} / \mathrm{G}$ genotype in the first sleep cycle $\left(F_{(2,50)}=2.361, p=0.047\right)$. The $p$ values in bold type indicate statistical significance.

*In case of significant MANOVA outcome, two-tailed unpaired post hoc $t$ test.

**Sleep efficiency is the ratio of sleep to time spent in bed shown as a percentage.

sleep continuity in heterozygous participants $(\mathrm{A} / \mathrm{G})$ compared with homozygous (A/A) participants. The sleep period time was reduced, whereas the sleep onset latency was increased in subjects with the heterozygous genotype (Table 3 ). In view of the impaired sleep structure in transgenic animals (more frequent entries to the REMS in heterozygous $h P 2 X 7 R$ mice) as well as a tendency to lower sleep continuity in humans with the A/G genotype, we investigated the influence of genotype on sleep phase stability (frequency of entries into REMS and NREMS). Since typical sleep abnormalities in depression occur at the beginning of a night's sleep (Dresler et al., 2014), we analyzed the first sleep cycle. A/G carriers showed a significant increase in the number of entries into shallow sleep from NREMS stage 2. Additional parameters describing the direction of NREM entries [stage 2 into shallow sleep or wakefulness; slow-wave sleep (SWS) into shallow sleep or wakefulness] revealed that the sleep of A/G carriers was characterized by a significant instability of stage 2 sleep (higher numbers of entries from stage 2 sleep into shallow sleep or wakefulness) during the first sleep cycle (Table 3 ).

The genotype effect on NREMS EEG frequency spectrum morphology is particularly related to sleep spindles. A/G carriers exhibited an increased amount of spectral power in spindle frequency. Two-way mixed-model ANOVA with the between-subject factor genotype $(\mathrm{A} / \mathrm{A}, \mathrm{A} / \mathrm{G})$ and the within-subject factor derivation (F3A2, C3A3, P3A2, and O1A2) performed for EEG power frequency bins in NREM sleep revealed a significant main effect of genotype at $13 \mathrm{~Hz}\left(F_{(1,51)}=4.592, p=0.037\right.$; Fig. $\left.4 A, B\right)$. Correspondingly, the mean peak frequency of sleep spindles was significantly lower in these subjects (two-tailed unpaired $t$ test: $p=$ 0.001 ; Fig. 4C). In addition, the NREMS spectrum of A/G carriers displayed a higher number of beta frequencies at $25-26 \mathrm{~Hz}$ (twoway mixed ANOVA: genotype: $F_{(1,51)} \geq 4.614, p \leq 0.036$; Fig. $4 A, B)$. REM sleep parameters or characteristics of SWS did not differ between genotypes (Table 3 ).

\section{hP2X7R mice respond to chronic stress}

The reduced sleep quality observed in mice, and to a milder degree also present in humans, led us to hypothesize that it might reflect signs of a presymptomatic disease stage or indicate an increased vulnerability of heterozygote individuals to the development of symptoms of mood disorders. In general, the disease risk is determined by the interaction of a genetic predisposition with environmental factors such as chronic stress or severe trauma. To test this hypothesis, we subjected hP2X7R mice to 3 weeks of CSDS. In accordance with previous studies (Wagner et al., 2011; Wang et al., 2011; Hartmann et al., 2012a,b; Gassen et al., 2014), $h P 2 X 7 R$ mice showed robust physiological and neuroendocrine changes evoked by CSDS. These included the following: fur quality decrease (RM ANOVA: time: $F_{(3,116)}=84.9$, $p<0.001$; time $\times$ stress: $F_{(3,116)}=63.9, p<0.001$; time $\times$ genotype: $F_{(6,234)}=0.74, p=0.62$; time $\times$ genotype $\times$ stress: $F_{(6,234)}=1.1, p=0.39$; stress: $F_{(1,118)}=190.8, p<0.001$; genotype: $F_{(2,118)}=0.53, p=0.59$; genotype $\times$ stress: $F_{(2,118)}=0.11$, $p=0.68 ; n=20-23$; Fig. $5 A$ ), thymus atrophy (two-way ANOVA: stress: $F_{(1,122)}=26.14, p<0.001$; genotype: $F_{(2,122)}=$ $0.39, p=0.68$; genotype $\times$ stress: $F_{(2,122)}=0.59, p=0.56 ; n=$ 20-23; Fig. $5 B$ ), adrenal gland enlargement (two-way ANOVA: stress: $F_{(1,119)}=65.88, p<0.0001$; genotype: $F_{(2,119)}=0.12, p=$ 0.89 ; genotype $\times$ stress: $F_{(2,119)}=1.0, p=0.37 ; n=20-23$; Fig. 
A

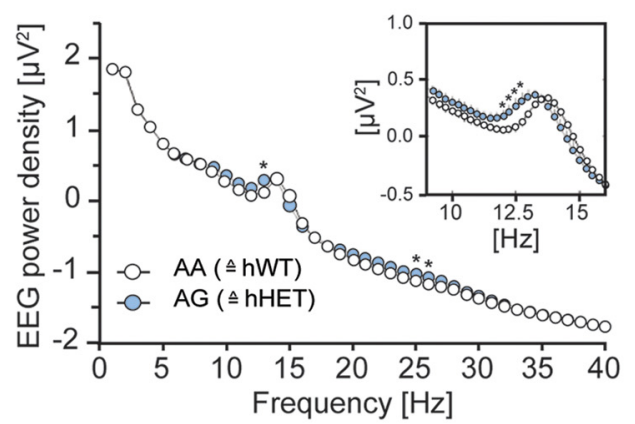

C

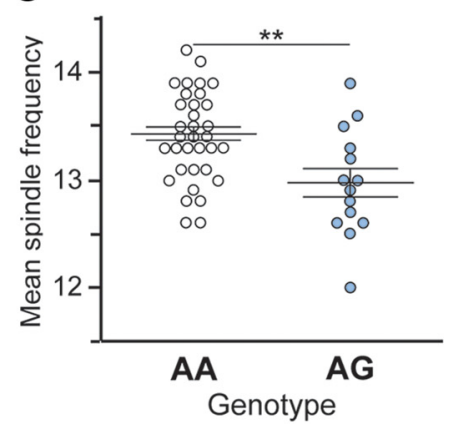

B

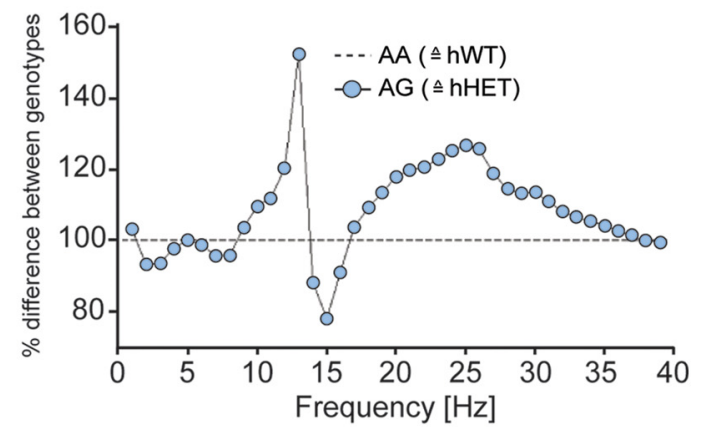

Figure 4. Heterozygosity alters sleep parameters in humans. A, EEG power spectra (log-transformed) during NREMS between homozygous (A/A) and heterozygous (A/G) healthy participants. EEG power density in the heterozygous genotype was significantly higher in the 13, 25, and $26 \mathrm{~Hz}$ bins (two-way mixed ANOVA with the between-subject factor genotype and the within-subject factor derivation for $\mathrm{F} 3 \mathrm{~A} 2, \mathrm{C} 3 \mathrm{~A} 2, \mathrm{P3A2}$, and $01 \mathrm{A2} ;{ }^{*} \mathrm{p}<0.05$ ). $\boldsymbol{B}$, The genotype effect on power density was most prominent in parietal $\mathrm{EEG}$ derivation (P3A2) in the $13 \mathrm{~Hz}$ bin. $\boldsymbol{C}$, The $13 \mathrm{~Hz}$ frequency in human EEG overlaps with sleep spindles activity, whose frequency usually varies between 12 and $15 \mathrm{~Hz}$. Heterozygous $\mathrm{A} / \mathrm{G}$ carriers showed a significantly lower mean peak frequency of all sleep spindles detected in parietal (P3A2) EEG derivation within NREMS (two-tailed unpaired $t$ test, ${ }^{* *} p=0.001$ ).

$5 C)$ as well as sensitization of the hypothalamic-pituitary-adrenal axis to a novel stressor (two-way ANOVA: stress: $F_{(1,43)}=20.05, p<$ 0.0001 ; genotype: $F_{(2,43)}=0.19, p=0.83$; genotype $\times$ stress: $F_{(2,43)}=$ $1.16, p=0.32 ; n=8-10$; Fig. $5 D)$. We did not detect significant genotype effects in any of the assessed parameters, indicating that the CSDS paradigm evoked similar strong effects in all three genotypes.

We then performed a wide range of behavioral tests to assess the consequences of CSDS on core endophenotypes related to mood disorders. Again, we observed no alterations in any behavioral readout in nonstressed control groups. In line with previous studies, chronically stressed $h P 2 R X 7$ mice showed decreased locomotion in the OF test compared with unstressed mice (RM ANOVA: time: $F_{(2,50)}=3.25, p=0.05$; time $\times$ stress: $F_{(2,50)}=$ $1.45, p=0.24$; time $\times$ genotype: $F_{(4,102)}=1.36, p=0.25$; time $\times$ genotype $\times$ stress: $F_{(4,102)}=1.45, p=0.23$; stress: $F_{(1,51)}=10.48$, $p<0.005$; genotype: $F_{(2,51)}=0.52, p=0.6$; genotype $\times$ stress: $\left.F_{(2,51)}=0.29, p=0.75 ; n=20-23\right)$. Although stressed $P 2 r x 7^{h H E T}$ mice appeared to show an increase in locomotion (two-way ANOVA: stress: $F_{(1,49)}=5.05, p=0.029$; genotype: $F_{(2,49)}=2.37$, $p=0.10$; genotype $\times$ stress: $\left.F_{(2,49)}=0.86, p=0.42 ; n=9-10\right)$ accompanied by decreased immobility (two-way ANOVA: stress: $F_{(1,49)}=12.34, p<0.001$; genotype: $F_{(2,49)}=2.57, p=0.09$; genotype $\times$ stress: $\left.F_{(2,49)}=0.39, p=0.67 ; n=9-10\right)$ during the first $5 \mathrm{~min}$ of the OF test, this did not reach statistical significance (Fig. 6A-C). In the EPM, all three genotypes displayed a similar increase in anxiety-related behavior following CSDS (two-way ANOVA: stress: $F_{(1,117)}=5.29, p=0.023$; genotype: $F_{(2,117)}=1.0$, $p=0.37$; genotype $\times$ stress: $F_{(2,117)}=0.44, p=0.64 ; n=19-23$; Fig. $6 D)$. Given that impairments in social behavior are reminiscent of various psychiatric clinical conditions including mood disorders (Nestler and Hyman, 2010), we also conducted the social avoid- ance test. Although two-way ANOVA revealed only a main significant effect of stress, $P 2 r x 7^{h H E T}$ and $P 2 r x 7^{h Q 460 R}$ mice spent less time in close proximity to the social target compared with P2r $x 7^{h W T}$ mice (two-way ANOVA: stress: $F_{(1,61)}=14.16, p<$ 0.001 ; genotype: $F_{(2,61)}=1.9, p=0.16$; genotype $\times$ stress: $F_{(2,61)}=$ $0.65, p=0.52 ; n=11-13$; Fig. $6 E)$. However, a significant stress effect was also observed during the empty wire cage trial of the social avoidance test, implying increased anxiety-related behavior in the animals even in the absence of a novel social counterpart (two-way ANOVA: stress: $F_{(1,61)}=8.94, p=0.004$; genotype: $F_{(2,61)}=2.48, p=0.09$; genotype $\times$ stress: $F_{(2,61)}=0.25, p=0.78$; $n=11-13$; Fig. $6 F$ ). We also applied the FUST to assess anhedonia but found no statistically significantly differences between genotypes following CSDS (two-way ANOVA: stress: $F_{(1,59)}=$ $7.42, p=0.008$; genotype: $F_{(2,59)}=1.46, p=0.24$; genotype $\times$ stress: $F_{(2,59)}=0.47, p=0.63 ; ; n=10-12 ;$ Fig. $\left.6 G\right)$. CSDS had no effect on sniffing behavior when water was used as a control (Fig. $6 H$ ). Together, the analyses of $h P 2 R X 7$ mice do not provide sufficient evidence that the hP2X7R-WT/hP2X7R-Gln460Arg heterozygosity conveys an increased vulnerability to develop mood disorder-related endophenotypes in adult mice in response to chronic social defeat stress.

\section{Discussion}

\section{Modeling human genetic findings in the mouse}

In recent years, considerable efforts have led to the identification of genetic variants associated with psychiatric disorders (Collins and Sullivan, 2013). However, most discoveries lack experimental validation in an appropriate genetic animal model owing to the fact that the vast majority of disease-associated SNPs are of unknown function and are not conserved between humans and 
rodents. In contrast, nonsynonymous or regulatory SNPs that directly impact amino acid sequence or gene function are exceptionally rare (Chen et al., 2006).

In the case of the P2X7R, we took advantage of the fact that the disease-associated Gln460Arg polymorphism enables us to readily model the genetic association in mice and thereby address its immediate function in vivo. The relevance of $\mathrm{P} 2 \mathrm{X} 7 \mathrm{R}$ in vivo with regard to phenotypes related to mood disorders has so far been investigated using only constitutive P2X7R KO mice (Solle et al., 2001; Basso et al., 2009; Boucher et al., 2011; Csölle et al., 2013). However, the direct translation of these findings is difficult considering that human genetic studies associated a polymorphism leading to an amino acid substitution with mood disorders but not a null allele (Barden et al., 2006; Lucae et al., 2006; Hejjas et al., 2009; McQuillin et al., 2009; Soronen et al., 2011). To interrogate the P2X7RGln460Arg polymorphism in vivo, we generated humanized mice by substituting the murine P2X7R with the human P2X7R variants. We confirmed in $h P 2 R X 7$ mice previous reports demonstrating that the P2X7R-Gln460Arg variant itself is not significantly impaired in its function compared with the WT P2X7R (Roger et al., 2010). However, the coexpression of the mood disorder-associated P2X7R-

Gln460Arg variant with WT P2X7R caused a significant reduction in normal receptor function, which was reflected by an attenuated calcium response of primary hippocampal cells derived from heterozygous $h P 2 R X 7$ mice. This is in line with a recent study (Aprile-Garcia et al., 2016) using stably transfected HEK293 cells coexpressing both $\mathrm{P} 2 \mathrm{X} 7 \mathrm{R}$ variants, which also showed a reduced calcium uptake. Despite the significantly altered P2X7R function in heterozygous $h P 2 R X 7$ mice, no significant genotype-dependent behavioral alterations were detected under basal housing conditions.

\section{Heterozygosity affects sleep}

It has been shown that P2X7R expression is under circadian control and is increased following sleep deprivation in humans (Backlund et al., 2012). Moreover, P2X7R directly modulates the action of somnogenic cytokines including IL- $1 \beta$ and tumor necrosis factor $\alpha$, which are recognized as endogenous sleep regulatory substances (SRSs; Krueger et al., 2010). Here we observed that $\mathrm{hP} 2 \mathrm{X} 7 \mathrm{R}$ mice displayed normal nocturnal sleep-wake behavior. However, heterozygous hP2X7R mice showed overt alterations in their sleep architecture compared with homozygous littermates. Comparable impairments of sleep, including an increased proportion of REMS and reduced slow-wave activity during NREMS, are often seen in patients with mood disorders (Modell and Lauer, 2007; Germain and Kupfer, 2008). Sleep-EEG recordings in healthy human subjects, genotyped for rs2230912, revealed NREMS instability and alterations in NREMS morphology in heterozygous carriers. In particular, heterozygous A/G carriers showed a lower mean peak frequency of all sleep spindles in both slow-wave sleep and stage 2 sleep. In view of the relevance of changes in either the number or the oscillation frequency of sleep spindles in several neuropsychiatric diseases and brain function in general (Ferrarelli et al., 2007; Lopez et al., 2010; Christensen et al., 2015; Nishida et al., 2016; Pótári et al., 2017), the observed slowing of spindle frequency may indicate a subtle but sensitive sleep alteration. The prominent role of P2X7R in cytokine release suggests that low EEG power seen in heterozygous hP2RX7 mice might result from interference with SRSs. Moreover, the fact that changes in immune mediators such as proinflammatory cytokines are repeatedly observed in patients with mood disorders further supports a potential role of P2X7R in disease etiology (Kronfol and Remick, 2000; Stokes et al., 2015). Together, heterozygous hP2X7R mice showed depression-like changes in both NREMS and REMS, whereas in healthy human A/G carriers subtle sleep changes were restricted to NREMS. These findings might hint toward early disease symptoms or signs of a prodromal state, which have the potential to convey increased vulnerability to the development of disease (Perlis et al., 1997).

\section{Gene $\times$ environment interactions}

There is ample evidence that individual disease vulnerability is not purely genetically determined (Caspi and Moffitt, 2006) but is strongly linked to environmental factors such as stress. Sustained or chronic stress and a maladaptive stress response in combination with a genetic predisposition are able to trigger the precipitation of mood disorders, which are consequently often regarded as stressrelated disorders (de Kloet et al., 2005). To test whether heterozygosity might predispose to disease development, we subjected $h P 2 X 7 R$ mice to the widely used and repeatedly validated CSDS paradigm 

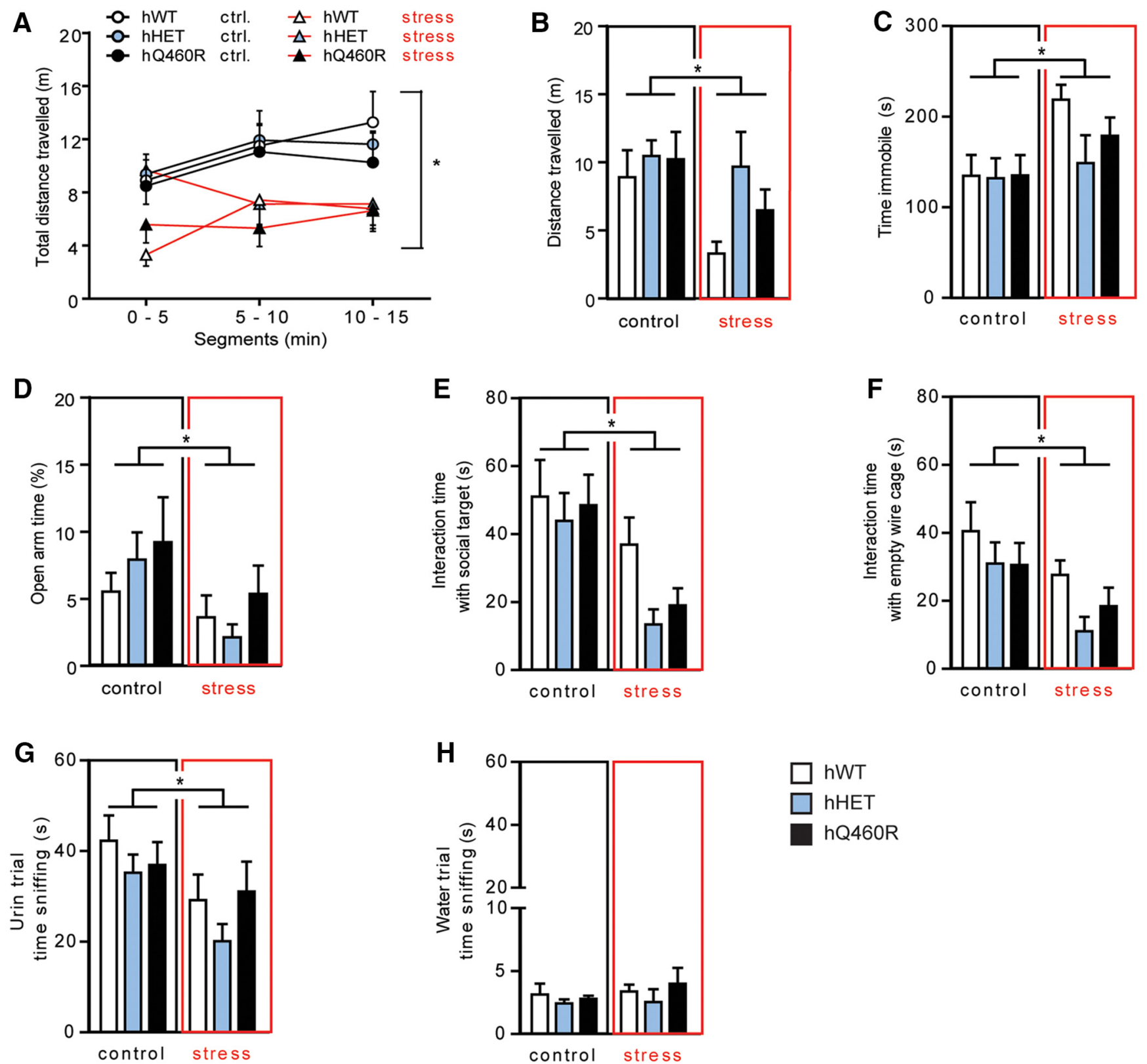

Figure 6. CSDS induces robust behavioral deficits in $h P 2 R X 7$ mice. $A, B, C S D S$ induced an overall decrease in locomotion in $\mathrm{hP} 2 X 7 \mathrm{R}$ mice in the $0 \mathrm{~F}$ when assessed for the entire test duration (15 $\mathrm{min} ; \boldsymbol{A})$ as well as in the initial $5 \mathrm{~min}(\boldsymbol{B}) . \boldsymbol{C}$, Accordingly, immobility in the $0 \mathrm{~F}$ was significantly increased during the first $5 \mathrm{~min}$ of the $0 \mathrm{~F}$ test. $\boldsymbol{D}, h P 2 R X 7$ mice showed an enhanced anxiety response to CSDS in the elevated plus maze. $\boldsymbol{E}$, CSDS evoked a decreased interaction time with the social target in $h P 2 R X 7$ mice during the social avoidance paradigm. $\boldsymbol{F}$, However, $h P 2 R X 7$ mice also spent significantly less time interacting with the empty wire cage during the first trial of the social avoidance task. $G$, During the female urine sniffing test, a decrease in time spent sniffing estrus female urine was observed in all stressed $h P 2 R X 7$ animals compared with nonstressed controls. $\boldsymbol{H}$, No significant genotype and/or condition differences were detectable in the water trial of the female urine sniffing test. Data are expressed as the mean \pm SEM. ${ }^{*} p<0.05$.

(Berton et al., 2006; Hartmann et al., 2012a). Chronic stress can have a major impact on the behavioral phenotype of animals, often resulting in diminished locomotor activity and higher anxiety-related behavior (Berton et al., 2006; Hartmann et al., 2012a). Accordingly, all genotypes of $h P 2 X 7 R$ mice showed reduced locomotion in the 15 min OF test and increased anxiety in the EPM. Moreover, stressed $h P 2 X 7 R$ mice showed a clearly increased social avoidance as well as signs of anhedonia. Even though heterozygous $h P 2 X 7 R$ mice displayed the strongest effect of CSDS, two-way analyses of variants did not reveal statistically significant interaction effects in any of the behavioral tests. These behavioral paradigms assessed the cardinal symptoms of mood disorders, including locomotion, and anxietyrelated, social, and anhedonic behavior (Nestler and Hyman, 2010).
However, further studies evaluating different aspects of cognition, anhedonia (sucrose-preference), and anxiety (e.g., fear memory and learned helplessness) in conjunction with other chronic stress paradigms will further refine the contribution of $\mathrm{P} 2 \mathrm{RX} 7$ polymorphisms in mood disorders. Nevertheless, together with the observed sleep alterations, we believe that our results provide important and relevant biological evidence that heterozygosity for wild-type P2X7R mice and the P2X7R-Q460R variant represents a genetic risk factor for mood disorders.

\section{A heterozygote disadvantage model}

To the best of our knowledge, the P2X7R is the first example suggesting a heterozygote disadvantage model for the association 
of a candidate SNP with psychiatric disorders (Lucae et al., 2006). It would be interesting to investigate this model in a meta-analysis similar to the recent study by Feng et al. (2014). Coexpression and interaction of P2X7R subunits, either with splice or polymorphic variants, may represent a general mechanism for the regulation of P2X7R activity and other ion channels. However, this mechanism appears unique as it has not been described for any of the numerous other P2X7R variants. A first hint of an underlying mechanism involving interaction with the P2X7R-WT emerges from a naturally occurring truncated variant of $\mathrm{P} 2 \mathrm{X} 7 \mathrm{R}$, which is ineffective when expressed alone but is able to hetero-oligomerize with P2X7R-WT, thereby blocking P2X7R activity (Feng et al., 2006). Similarly, C-terminally truncated variants of P2X7R, escaping inactivation in KO mice (Solle et al., 2001) and variants bearing mutations in the extracellular domain have been reported to act in a dominant-negative fashion (Raouf et al., 2004; Masin et al., 2012).

Of note, P2X7 excels compared with all other P2X family members with respect to the frequency of nonsynonymous SNPs, which might to some extent reflect evolutionary adaptation related to the role of P2X7R in modulating innate immune function (Sluyter and Stokes, 2011; Wiley et al., 2011). Nevertheless, further structural insights are required to mechanistically understand the functional consequences of the coexpression of hP2X7R-WT with hP2X7R-Gln460Arg and its implication in mood disorders.

\section{Conclusions}

In conclusion, the herein reported results involving studies in human participants and respective mouse models suggest that heterozygosity for P2X7R-WT and P2X7R-Gln460Arg genetically predisposes to enhanced stress vulnerability. This is causally linked to the coexpression of P2X7R-WT and P2X7R-Gln460Arg variants, which results in a significant reduction of normal $\mathrm{P} 2 \mathrm{X} 7 \mathrm{R}$ function. Our findings suggest that the alterations in P2X7R function in heterozygote mice convey disturbances in mechanisms of sleep regulation. These findings together with the subtle changes in NREMS parameters in heterozygous human subjects have the potential to open up potential novel diagnostic and therapeutic avenues. Taking into account that sleep-EEG alterations are robust predictors of an emergent depressive episode and may even precede the full-blown clinical syndrome (Steiger and Kimura, 2010), our results suggest that observed changes in sleep variables in combination with a heterozygous rs2230912 genotype could represent a predictor or biomarker for the risk of mood disorders. Our study provides strong evidence for a heterozygote disadvantage model, which adds a new perspective to the current knowledge of functional mechanisms underlying genetic findings in complex diseases.

\section{References}

Abkevich V, Camp NJ, Hensel CH, Neff CD, Russell DL, Hughes DC, Plenk AM, Lowry MR, Richards RL, Carter C, Frech GC, Stone S, Rowe K, Chau CA, Cortado K, Hunt A, Luce K, O’Neil G, Poarch J, Potter J, et al (2003) Predisposition locus for major depression at chromosome 12q22-12q23.2. Am J Hum Genet 73:1271-1281. CrossRef Medline

Adamczyk M, Ambrosius U, Lietzenmaier S, Wichniak A, Holsboer F, Friess E (2015) Genetics of rapid eye movement sleep in humans. Transl Psychiatry 5:e598. CrossRef Medline

Aprile-Garcia F, Metzger MW, Paez-Pereda M, Stadler H, Acuña M, Liberman AC, Senin SA, Gerez J, Hoijman E, Refojo D, Mitkovski M, Panhuysen M, Stühmer W, Holsboer F, Deussing JM, Arzt E (2016) Co-expression of wild-type P2X7R with Gln460Arg variant alters receptor function. PLoS One 11:e0151862. CrossRef Medline

Backlund L, Nikamo P, Hukic DS, Ek IR, Träskman-Bendz L, Landén M, Edman G, Schalling M, Frisén L, Osby U (2011) Cognitive manic symp- toms associated with the P2RX7 gene in bipolar disorder. Bipolar Disord 13:500-508. CrossRef Medline

Backlund L, Lavebratt C, Frisén L, Nikamo P, Hukic Sudic D, TräskmanBendz L, Landén M, Edman G, Vawter MP, Ösby U, Schalling M (2012) P2RX7: expression responds to sleep deprivation and associates with rapid cycling in bipolar disorder type 1. PLoS One 7:e43057. CrossRef Medline

Barden N, Harvey M, Gagné B, Shink E, Tremblay M, Raymond C, Labbé M, Villeneuve A, Rochette D, Bordeleau L, Stadler H, Holsboer F, MüllerMyhsok B (2006) Analysis of single nucleotide polymorphisms in genes in the chromosome 12Q24.31 region points to $\mathrm{P} 2 \mathrm{RX} 7$ as a susceptibility gene to bipolar affective disorder. Am J Med Genet B Neuropsychiatr Genet 141B:374-382. CrossRef Medline

Bartlett R, Stokes L, Sluyter R (2014) The P2X7 receptor channel: recent developments and the use of $\mathrm{P} 2 \mathrm{X} 7$ antagonists in models of disease. Pharmacol Rev 66:638-675. CrossRef Medline

Basso AM, Bratcher NA, Harris RR, Jarvis MF, Decker MW, Rueter LE (2009) Behavioral profile of P2X7 receptor knockout mice in animal models of depression and anxiety: relevance for neuropsychiatric disorders. Behav Brain Res 198:83-90. CrossRef Medline

Berton O, McClung CA, Dileone RJ, Krishnan V, Renthal W, Russo SJ, Graham D, Tsankova NM, Bolanos CA, Rios M, Monteggia LM, Self DW, Nestler EJ (2006) Essential role of BDNF in the mesolimbic dopamine pathway in social defeat stress. Science 311:864-868. CrossRef Medline

Bosker FJ, Hartman CA, Nolte IM, Prins BP, Terpstra P, Posthuma D, van Veen T, Willemsen G, DeRijk RH, de Geus EJ, Hoogendijk WJ, Sullivan PF, Penninx BW, Boomsma DI, Snieder H, Nolen WA (2011) Poor replication of candidate genes for major depressive disorder using genomewide association data. Mol Psychiatry 16:516-532. CrossRef Medline

Boucher AA, Arnold JC, Hunt GE, Spiro A, Spencer J, Brown C, McGregor IS, Bennett MR, Kassiou M (2011) Resilience and reduced c-Fos expression in P2X7 receptor knockout mice exposed to repeated forced swim test. Neuroscience 189:170-177. CrossRef Medline

Caspi A, Moffitt TE (2006) Gene-environment interactions in psychiatry: joining forces with neuroscience. Nat Rev Neurosci 7:583-590. CrossRef Medline

Chen ZY, Jing D, Bath KG, Ieraci A, Khan T, Siao CJ, Herrera DG, Toth M, Yang C, McEwen BS, Hempstead BL, Lee FS (2006) Genetic variant BDNF (Val66Met) polymorphism alters anxiety-related behavior. Science 314:140-143. CrossRef Medline

Christensen JA, Nikolic M, Warby SC, Koch H, Zoetmulder M, Frandsen R, Moghadam KK, Sorensen HB, Mignot E, Jennum PJ (2015) Sleep spindle alterations in patients with Parkinson's disease. Front Hum Neurosci 9:233. CrossRef Medline

Collins AL, Sullivan PF (2013) Genome-wide association studies in psychiatry: what have we learned? Br J Psychiatry 202:1-4. CrossRef Medline

Collins PY, Patel V, Joestl SS, March D, Insel TR, Daar AS, Daar AS, Anderson W, Dhansay MA, Phillips A, Shurin S, Walport M, Ewart W, Savill SJ, Bordin IA, Costello EJ, Durkin M, Fairburn C, Glass RI, Hall W, et al (2011) Grand challenges in global mental health. Nature 475:27-30. CrossRef Medline

Csölle C, Andó RD, Kittel Á, Gölöncsér F, Baranyi M, Soproni K, Zelena D, Haller J, Németh T, Mócsai A, Sperlágh B (2013) The absence of P2X7 receptors (P2rx7) on non-haematopoietic cells leads to selective alteration in mood-related behaviour with dysregulated gene expression and stress reactivity in mice. Int J Neuropsychopharmacol 16:213-233. CrossRef Medline

Degn B, Lundorf MD, Wang A, Vang M, Mors O, Kruse TA, Ewald H (2001) Further evidence for a bipolar risk gene on chromosome 12q24 suggested by investigation of haplotype sharing and allelic association in patients from the Faroe Islands. Mol Psychiatry 6:450-455. CrossRef Medline

de Kloet ER, Joëls M, Holsboer F (2005) Stress and the brain: from adaptation to disease. Nat Rev Neurosci 6:463-475. CrossRef Medline

Deuchars SA, Atkinson L, Brooke RE, Musa H, Milligan CJ, Batten TF, Buckley NJ, Parson SH, Deuchars J (2001) Neuronal P2X7 receptors are targeted to presynaptic terminals in the central and peripheral nervous systems. J Neurosci 21:7143-7152. Medline

Dresler M, Spoormaker VI, Beitinger P, Czisch M, Kimura M, Steiger A, Holsboer F (2014) Neuroscience-driven discovery and development of sleep therapeutics. Pharmacol Ther 141:300-334. CrossRef Medline

Feng WP, Zhang B, Li W, Liu J (2014) Lack of association of P2RX7 gene rs2230912 polymorphism with mood disorders: a meta-analysis. PLoS One 9:e88575. CrossRef Medline 
Feng YH, Li X, Wang L, Zhou L, Gorodeski GI (2006) A truncated P2X7 receptor variant $(\mathrm{P} 2 \mathrm{X} 7-\mathrm{j})$ endogenously expressed in cervical cancer cells antagonizes the full-length $\mathrm{P} 2 \mathrm{X} 7$ receptor through hetero-oligomerization. J Biol Chem 281:17228-17237. CrossRef Medline

Ferrarelli F, Huber R, Peterson MJ, Massimini M, Murphy M, Riedner BA, Watson A, Bria P, Tononi G (2007) Reduced sleep spindle activity in schizophrenia patients. Am J Psychiatry 164:483-492. CrossRef Medline

Gassen NC, Hartmann J, Zschocke J, Stepan J, Hafner K, Zellner A, Kirmeier T, Kollmannsberger L, Wagner KV, Dedic N, Balsevich G, Deussing JM, Kloiber S, Lucae S, Holsboer F, Eder M, Uhr M, Ising M, Schmidt MV, Rein T (2014) Association of FKBP51 with priming of autophagy pathways and mediation of antidepressant treatment response: evidence in cells, mice, and humans. PLoS Med 11:e1001755. CrossRef Medline

Germain A, Kupfer DJ (2008) Circadian rhythm disturbances in depression. Hum Psychopharmacol 23:571-585. CrossRef Medline

Green EK, Grozeva D, Raybould R, Elvidge G, Macgregor S, Craig I, Farmer A, McGuffin P, Forty L, Jones L, Jones I, O’Donovan MC, Owen MJ, Kirov G, Craddock N (2009) P2RX7: a bipolar and unipolar disorder candidate susceptibility gene? Am J Med Genet B Neuropsychiatr Genet 150B: 1063-1069. CrossRef Medline

Grigoroiu-Serbanescu M, Herms S, Mühleisen TW, Georgi A, Diaconu CC, Strohmaier J, Czerski P, Hauser J, Leszczynska-Rodziewicz A, Jamra RA, Babadjanova G, Tiganov A, Krasnov V, Kapiletti S, Neagu AI, Vollmer J, Breuer R, Rietschel M, Nöthen MM, Cichon S, et al (2009) Variation in P2RX7 candidate gene (rs2230912) is not associated with bipolar I disorder and unipolar major depression in four European samples. Am J Med Genet B Neuropsychiatr Genet 150B:1017-1021. CrossRef Medline

Halmai Z, Dome P, Vereczkei A, Abdul-Rahman O, Szekely A, Gonda X, Faludi G, Sasvari-Szekely M, Nemoda Z (2013) Associations between depression severity and purinergic receptor P2RX7 gene polymorphisms. J Affect Disord 150:104-109. CrossRef Medline

Hartmann J, Wagner KV, Dedic N, Marinescu D, Scharf SH, Wang XD, Deussing JM, Hausch F, Rein T, Schmidt U, Holsboer F, Müller MB, Schmidt MV (2012a) Fkbp52 heterozygosity alters behavioral, endocrine and neurogenetic parameters under basal and chronic stress conditions in mice. Psychoneuroendocrinology 37:2009-2021. CrossRef Medline

Hartmann J, Wagner KV, Liebl C, Scharf SH, Wang XD, Wolf M, Hausch F, Rein T, Schmidt U, Touma C, Cheung-Flynn J, Cox MB, Smith DF, Holsboer F, Müller MB, Schmidt MV (2012b) The involvement of FK506-binding protein 51 (FKBP5) in the behavioral and neuroendocrine effects of chronic social defeat stress. Neuropharmacology 62:332339. CrossRef Medline

Hejjas K, Szekely A, Domotor E, Halmai Z, Balogh G, Schilling B, Sarosi A, Faludi G, Sasvari-Szekely M, Nemoda Z (2009) Association between depression and the Gln460Arg polymorphism of P2RX7 gene: a dimensional approach. Am J Med Genet B Neuropsychiatr Genet 150B:295299. CrossRef Medline

Khakh BS, North RA (2006) P2X receptors as cell-surface ATP sensors in health and disease. Nature 442:527-532. CrossRef Medline

Kimura M, Müller-Preuss P, Lu A, Wiesner E, Flachskamm C, Wurst W, Holsboer F, Deussing JM (2010) Conditional corticotropin-releasing hormone overexpression in the mouse forebrain enhances rapid eye movement sleep. Mol Psychiatry 15:154-165. CrossRef Medline

Kronfol Z, Remick DG (2000) Cytokines and the brain: implications for clinical psychiatry. Am J Psychiatry 157:683-694. CrossRef Medline

Krueger JM, Taishi P, De A, Davis CJ, Winters BD, Clinton J, Szentirmai E, Zielinski MR (2010) ATP and the purine type 2 X7 receptor affect sleep. J Appl Physiol (1985) 109:1318-1327. CrossRef

Lavebratt C, Aberg E, Sjöholm LK, Forsell Y (2010) Variations in FKBP5 and BDNF genes are suggestively associated with depression in a Swedish population-based cohort. J Affect Disord 125:249-255. CrossRef Medline

Lopez J, Hoffmann R, Armitage R (2010) Reduced sleep spindle activity in early-onset and elevated risk for depression. J Am Acad Child Adolesc Psychiatry 49:934-943. CrossRef Medline

Lucae S, Salyakina D, Barden N, Harvey M, Gagné B, Labbé M, Binder EB, Uhr M, Paez-Pereda M, Sillaber I, Ising M, Brückl T, Lieb R, Holsboer F, Müller-Myhsok B (2006) P2RX7, a gene coding for a purinergic ligandgated ion channel, is associated with major depressive disorder. Hum Mol Genet 15:2438-2445. CrossRef Medline

Malkesman O, Scattoni ML, Paredes D, Tragon T, Pearson B, Shaltiel G, Chen G, Crawley JN, Manji HK (2010) The female urine sniffing test: a novel approach for assessing reward-seeking behavior in rodents. Biol Psychiatry 67:864-871. CrossRef Medline

Masin M, Young C, Lim K, Barnes SJ, Xu XJ, Marschall V, Brutkowski W, Mooney ER, Gorecki DC, Murrell-Lagnado R (2012) Expression, assembly and function of novel C-terminal truncated variants of the mouse P2X7 receptor: re-evaluation of P2X7 knockouts. Br J Pharmacol 165: 978-993. CrossRef Medline

McQuillin A, Bass NJ, Choudhury K, Puri V, Kosmin M, Lawrence J, Curtis D, Gurling HM (2009) Case-control studies show that a non-conservative amino-acid change from a glutamine to arginine in the P2RX7 purinergic receptor protein is associated with both bipolar- and unipolar-affective disorders. Mol Psychiatry 14:614-620. CrossRef Medline

Metzger MW, Walser SM, Aprile-Garcia F, Dedic N, Chen A, Holsboer F, Arzt E, Wurst W, Deussing JM (2017) Genetically dissecting P2rx7 expression within the central nervous system using conditional humanized mice. Purinergic Signal 13:153-170. CrossRef Medline

Miras-Portugal MT, Díaz-Hernandez M, Giráldez L, Hervás C, GómezVillafuertes R, Sen RP, Gualix J, Pintor J (2003) P2X7 receptors in rat brain: presence in synaptic terminals and granule cells. Neurochem Res 28:1597-1605. CrossRef Medline

Modell S, Lauer CJ (2007) Rapid eye movement (REM) sleep: an endophenotype for depression. Curr Psychiatry Rep 9:480-485. CrossRef Medline

Nagy G, Ronai Z, Somogyi A, Sasvari-Szekely M, Rahman OA, Mate A, Varga T, Nemoda Z (2008) P2RX7 Gln460Arg polymorphism is associated with depression among diabetic patients. Prog Neuropsychopharmacol Biol Psychiatry 32:1884-1888. CrossRef Medline

Nestler EJ, Hyman SE (2010) Animal models of neuropsychiatric disorders. Nat Neurosci 13:1161-1169. CrossRef Medline

Nicke A (2008) Homotrimeric complexes are the dominant assembly state of native P2X7 subunits. Biochem Biophys Res Commun 377:803-808. CrossRef Medline

Nishida M, Nakashima Y, Nishikawa T (2016) Slow sleep spindle and procedural memory consolidation in patients with major depressive disorder. Nat Sci Sleep 8:63-72. CrossRef Medline

Papp L, Vizi ES, Sperlágh B (2004) Lack of ATP-evoked GABA and glutamate release in the hippocampus of $\mathrm{P} 2 \mathrm{X} 7$ receptor-/- mice. Neuroreport 15:2387-2391. CrossRef Medline

Perlis ML, Giles DE, Buysse DJ, Tu X, Kupfer DJ (1997) Self-reported sleep disturbance as a prodromal symptom in recurrent depression. J Affect Disord 42:209-212. CrossRef Medline

Pótári A, Ujma PP, Konrad BN, Genzel L, Simor P, Körmendi J, Gombos F, Steiger A, Dresler M, Bódizs R (2017) Age-related changes in sleep EEG are attenuated in highly intelligent individuals. Neuroimage 146:554560. CrossRef Medline

Raouf R, Chakfe Y, Blais D, Speelman A, Boué-Grabot E, Henderson D, Séguéla P (2004) Selective knock-down of P2X7 ATP receptor function by dominant-negative subunits. Mol Pharmacol 65:646-654. CrossRef Medline

Rechtschaffen A, Kales A (1968) A Manual of Standardized Terminology, Techniques and Scoring System for Sleep Stages of Human Subjects. National Institutes of Health Publication No. 204. Washington, DC: US Government Printing Office.

Roger S, Mei ZZ, Baldwin JM, Dong L, Bradley H, Baldwin SA, Surprenant A, Jiang LH (2010) Single nucleotide polymorphisms that were identified in affective mood disorders affect ATP-activated P2X7 receptor functions. J Psychiatr Res 44:347-355. CrossRef Medline

Sluyter R, Stokes L (2011) Significance of P2X7 receptor variants to human health and disease. Recent Pat DNA Gene Seq 5:41-54. CrossRef Medline

Solle M, Labasi J, Perregaux DG, Stam E, Petrushova N, Koller BH, Griffiths RJ, Gabel CA (2001) Altered cytokine production in mice lacking P2X(7) receptors. J Biol Chem 276:125-132. CrossRef Medline

Soronen P, Mantere O, Melartin T, Suominen K, Vuorilehto M, Rytsälä H, Arvilommi P, Holma I, Holma M, Jylhä P, Valtonen HM, Haukka J, Isometsä E, Paunio T (2011) P2RX7 gene is associated consistently with mood disorders and predicts clinical outcome in three clinical cohorts. Am J Med Genet B Neuropsychiatr Genet 156B:435-447. Medline

Sperlágh B, Illes P (2014) P2X7 receptor: an emerging target in central nervous system diseases. Trends Pharmacol Sci 35:537-547. CrossRef Medline

Steiger A, Kimura M (2010) Wake and sleep EEG provide biomarkers in depression. J Psychiatr Res 44:242-252. CrossRef Medline

Stokes L, Fuller SJ, Sluyter R, Skarratt KK, Gu BJ, Wiley JS (2010) Two haplotypes of the $\mathrm{P} 2 \mathrm{X}(7)$ receptor containing the Ala-348 to Thr poly- 
morphism exhibit a gain-of-function effect and enhanced interleukin1beta secretion. FASEB J 24:2916-2927. CrossRef Medline

Stokes L, Spencer SJ, Jenkins TA (2015) Understanding the role of P2X7 in affective disorders-are glial cells the major players? Front Cell Neurosci 9:258. CrossRef Medline

Surprenant A, Rassendren F, Kawashima E, North RA, Buell G (1996) The cytolytic P2Z receptor for extracellular ATP identified as a P2X receptor (P2X7). Science 272:735-738. CrossRef Medline

Torres GE, Egan TM, Voigt MM (1999) Hetero-oligomeric assembly of P2X receptor subunits. Specificities exist with regard to possible partners. J Biol Chem 274:6653-6659. CrossRef Medline

Viikki M, Kampman O, Anttila S, Illi A, Setälä-Soikkeli E, Huuhka M, Mononen N, Lehtimäki T, Leinonen E (2011) P2RX7 polymorphisms Gln460Arg and His155Tyr are not associated with major depressive disorder or remission after SSRI or ECT. Neurosci Lett 493:127-130. CrossRef Medline

Wagner KV, Wang XD, Liebl C, Scharf SH, Müller MB, Schmidt MV (2011) Pituitary glucocorticoid receptor deletion reduces vulnerability to chronic stress. Psychoneuroendocrinology 36:579-587. CrossRef Medline
Wang XD, Chen Y, Wolf M, Wagner KV, Liebl C, Scharf SH, Harbich D, Mayer B, Wurst W, Holsboer F, Deussing JM, Baram TZ, Müller MB, Schmidt MV (2011) Forebrain CRHR1 deficiency attenuates chronic stress-induced cognitive deficits and dendritic remodeling. Neurobiol Dis 42:300-310. CrossRef Medline

Wiley JS, Sluyter R, Gu BJ, Stokes L, Fuller SJ (2011) The human P2X7 receptor and its role in innate immunity. Tissue Antigens 78:321-332. CrossRef Medline

Yen YC, Mauch CP, Dahlhoff M, Micale V, Bunck M, Sartori SB, Singewald N, Landgraf R, Wotjak CT (2012) Increased levels of conditioned fear and avoidance behavior coincide with changes in phosphorylation of the protein kinase $\mathrm{B}$ (AKT) within the amygdala in a mouse model of extremes in trait anxiety. Neurobiol Learn Mem 98:56-65. CrossRef Medline

Yosifova A, Mushiroda T, Stoianov D, Vazharova R, Dimova I, Karachanak S, Zaharieva I, Milanova V, Madjirova N, Gerdjikov I, Tolev T, Velkova S, Kirov G, Owen MJ, O'Donovan MC, Toncheva D, Nakamura Y (2009) Case-control association study of 65 candidate genes revealed a possible association of a SNP of HTR5A to be a factor susceptible to bipolar disease in Bulgarian population. J Affect Disord 117:87-97. CrossRef Medline 